\title{
Genetic syndromes with vascular malformations - update on molecular background and diagnostics
}

Adam Ustaszewski ${ }^{1,2}$, Joanna Janowska-Głowacka², Katarzyna Wołyńska², Anna Pietrzak ${ }^{3}$, Magdalena Badura-Stronka²

${ }^{1}$ Institute of Human Genetics, Polish Academy of Sciences, Poznan, Poland
2Department of Medical Genetics, Poznan University of Medical Sciences, Poznan,
Poland
${ }^{3}$ Department of Neurology, Poznan University of Medical Sciences, Poznan, Poland

Submitted: 19 April 2018; Accepted: 9 September 2018

Online publication: 25 February 2020

Arch Med Sci 2021; 17 (4): 965-991

DOI: https://doi.org/10.5114/aoms.2020.93260

Copyright (c) 2020 Termedia \& Banach

\author{
Corresponding author: \\ Adam Ustaszewski \\ Institute of Human Genetics \\ Polish Academy of Sciences \\ 32 Strzeszynska St \\ 60-479 Poznan, Poland \\ Phone: +48616579223 \\ E-mail: adam.ustaszewski@ \\ igcz.poznan.pl
}

\begin{abstract}
Vascular malformations are present in a great variety of congenital syndromes, either as the predominant or additional feature. They pose a major challenge to the clinician: due to significant phenotype overlap, a precise diagnosis is often difficult to obtain, some of the malformations carry a risk of life threatening complications and, for many entities, treatment is not well established. To facilitate their recognition and aid in differentiation, we present a selection of notable congenital disorders of vascular system development, distinguishing between the heritable germinal and sporadic somatic mutations as their causes. Clinical features, genetic background and comprehensible description of molecular mechanisms is provided for each entity.
\end{abstract}

Key words: arteriovenous malformation, vascular malformation, capillary malformation, venous malformation, arterial malformation, lymphatic malformation.

\section{Introduction}

Congenital vascular malformations (VMs) are disorders of vascular architecture development. They may involve any vessel type and are accordingly classified as capillary, venous, arterial, lymphatic and arteriovenous, any of which can occur alone or in combinations. Congenital VMs are not only a cosmetic issue, as they can lead to serious or even life-threatening complications including congestive heart failure, ischemia, brain and spinal cord stroke and glaucoma. Vascular malformations are a feature of numerous genetic syndromes. Due to the overlapping symptoms, the differential diagnosis of genetic syndromes with VMs may be troublesome [1, 2]. Moreover, the effect of a particular gene mutation is often pleiotropic, giving rise to multiple phenotypes. While most well-known VM syndromes are caused by a constitutional mutation, some are revealed to result from somatic mutations, present in only a fraction of cells in the body. 


\section{Capillary malformation-arteriovenous malformation syndrome}

Capillary malformations (CMs, port-wine stains) are the most common VMs, occurring in $0.3 \%$ of newborns [1]. Capillary malformations present as lightly colored, reddish to pink, flat, slow-flow cutaneous lesions in the form of irregularly shaped macules. They may be confused with other macular skin lesions such as naevus flammeus neonatorum, commonly known as angel's kiss or salmon patch. Unlike hemangiomas, however, capillary malformations do not diminish with age but tend to darken and thicken. Capillary malformations usually are sporadic lesions, although recently, familiar occurrence and genetic syndromes presenting with CMs have been reported [3].

The recently described capillary malformationarteriovenous malformation (CM-AVM) syndrome is an underdiagnosed condition, often considered a sporadic collection of infantile hemangiomas or "port-wine stain". The skin changes typical for CM-AVM syndrome are acquired macules or papules that are multifocal (present in more than one region or location of the body), small (ranging from less than $1 \mathrm{~cm}$ to $3 \mathrm{~cm}$ in diameter), round to oval in shape and pink to red in color [2]. They are often surrounded by a white halo suggesting vascular steal and show arterial flow on Doppler ultrasound. The CM-AVM is usually associated with high-flow arteriovenous malformations (AVMs) or arteriovenous fistulas (AVFs) in muscle, skin and other tissues (intracranial, intraspinal and interosseous AVMs have been described) [4]. Chee et al. reported on patients with skin CMs and nontraumatic cerebral hemorrhage due to intracranial AVM [5]. The authors estimate the frequency of the CM-AVM syndrome in patients with cerebral AVMs at between 15\% and 50\% [5]. Boon et al. suggested that patients with multiple atypical CMs should be assessed for high-flow lesions such as AVMs or AVFs [6]. In these patients, neuroimaging screening should be considered.

The differential diagnosis of CM-AVM syndrome should include Klippel-Trénaunay-Weber syndrome, Parkes Weber syndrome, hereditary hemorrhagic telangiectasia (HHT; Rendu-Osler-Weber syndrome) and hereditary benign telangiectasia (HBT), which is a mild variant of the HHT, and Sturge Weber syndrome. All these syndromes feature cutaneous VMs.

Mutations of the RASA 1 gene are responsible for several forms of VMs: CMs, AVMs, AVFs, singularly and in complex combinations, as in the rare Parkes Weber syndrome (PWS) [7, 8]. In 2002, two loci for hereditary CMs were identified on chromosome 5 (5q14-21 and 5q13-22). A year later, RASA1 (RAS p21 protein activator 1; OMIM 139150) was identified as a candidate gene for atypical CMs with
AVMs and AVFs; what is more, these alterations have been also observed sporadically in PWS [1, $9,10]$. This constellation of VMs related to RASA 1 mutations was named capillary malformation arteriovenous malformation syndrome (CM-AVM) [1]. Subsequently, a number of studies reported on atypical CMs caused by RASA 1 mutations [2, 3, 5, $6,11-23]$. It was demonstrated that alterations of RASA1 might also act as an additional factor in other vascular development disorders, including vein of Galen malformations (VOGMs) and HHT [24-26]. RASA1 encodes RAS p21 protein activator 1 ( 120 -RasGAP) consisting of five domains. It is a negative regulator of the Ras/MAPK and MAPK/ERK pathway, converting the Ras protein into its inactive GDP-coupled form $[6,27]$. The active GTP Ras form interacts with the Raf protein that is responsible for phosphorylation of proteins involved in cell growth, proliferation and differentiation $[28,29]$. The changes in p120-RasGAP concentration levels have an impact on angiogenesis [30]. The CM-AVM syndrome follows the pattern of autosomal dominant inheritance with incomplete penetrance and variable phenotype, in part due to the localized nature of VMs [31]. Interestingly, De Wijn reported $100 \%$ penetrance in patients with RASA1 deletion [14] while Carr et al. estimated the penetrance at 20\% [32]. Eerola et al. suggested a predominant inheritance pattern (similar to the one in glomuvenous and cerebral cavernous malformations) that requires a somatic second hit mutation, resulting in complete loss of function of the p120 RAS-Gap protein [1] (Figure 1) [33-38].

Arguably, other non-synonymous alterations present in other members of Ras/MAPK pathway may lead to vascular development disorders. Indeed, published data indicate that inactivating mutation of the EPHB4 gene which recruits and activates RASA1 may result in CM-AVM syndrome in non-RASA1 patients [39-40]. The transmembrane kinase receptor EPHB4 is required for the proper functioning of several processes such as intervening capillary beds and morphogenesis, which are crucial for the development of the vascular system [39, 41]. However, mutations in RASA1 are still considered the main factor responsible for the CM-AVM syndrome. Table I contains a brief summary of molecular screening results in patients with CM-AVM syndrome [42-45].

\section{Hereditary hemorrhagic telangiectasia}

Owing to the similar clinical features, HHT may be mistaken for other CM-AVM syndromes. It has an autosomal dominant inheritance with high penetrance but considerable intrafamilial variability. The incidence of HHT is estimated at $1 / 8,000$ in infants [46]. The hallmark of the syndrome is 


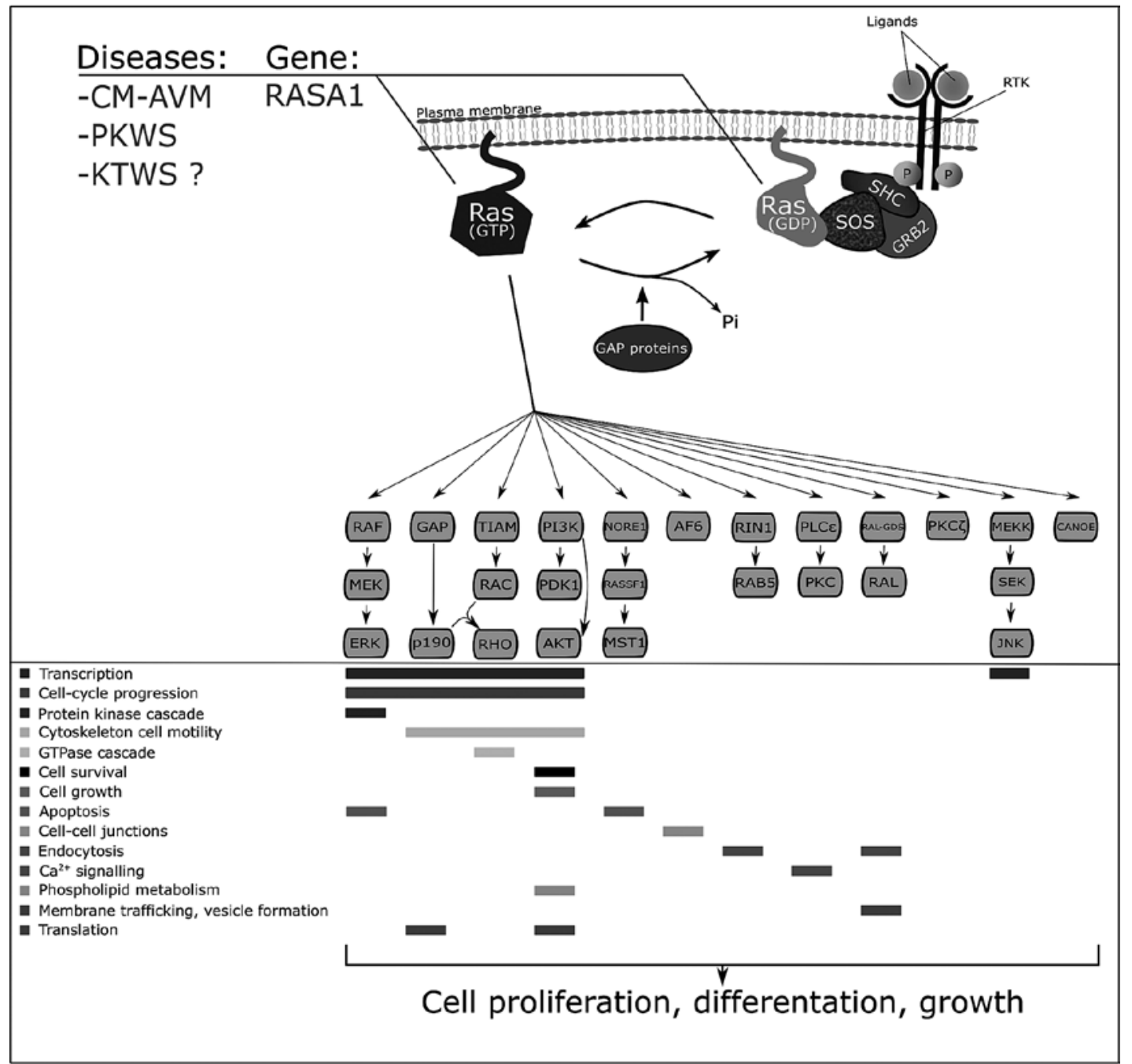

Figure 1. A simplified model of Ras activation as a part of the MAPK/ERK signaling pathway. Ras proteins play a key role in regulation of numerous subsequent signaling cascades and pathways. Mutations in the RASA1 gene may cause a change in Ras activity, resulting in development of CM-AVM syndrome and PWS. There is some evidence that KTWS might also be caused by abnormal Ras function. The complete genetic background of KTWS remains unknown [33-38]

multiple AVMs without intervening capillaries, resulting in direct connections between arteries and veins, affecting mucosae, skin and internal organs with co-occurrence of telangiectases. The HHT presentation is age-dependent. While the first symptoms are usually reported in adolescence, infants may also be affected. Commonly, HHT initially manifests with epistaxis and cutaneous or mucosal CMs that rupture and bleed after a minor trauma [47]. Ninety-five percent of with HHT suffer from recurrent epistaxis and $90 \%$ of affected individuals experience them before the age of 30 years [48]. The telangiectasias frequently affect the tongue, lips, buccal mucosa, face, chest, fingers, ears and conjunctivae. In adulthood, telangiectases develop in gastrointestinal mucosa. Stomach and duodenal mucosa is most frequently affected. It is estimated that approximately $25 \%$ of patients with HHT suffer from gastrointestinal bleeding, which usually occurs after the age of 50 years $[49,50]$. The AVMs localized in internal organs may have life-threatening manifestations. They are commonly found in lungs, liver and brain. In most cases, brain AVMs are already present at birth. They may manifest with intracerebral bleeding or epileptic seizures. It is estimated that $30-50 \%$ of patients with HHT syndrome bear pulmonary arteriovenous malformations [51]. Their rupture is the cause of hemoptysis. Pulmonary AVMs may also constitute a source of embolic material and cause vascular embolic incidents, including transient ischemic attacks (TIAs) and stroke, as well as brain and other organ abscesses; they may also lead to migraine-like headaches and polycythemia. Hepatic AVMs are usually asymptomatic. The common manifestations of hepatic vascular abnormalities are portal hypertension, high output heart failure and biliary disease. In the lanora et al. 
Table I. Mutations in RASA1 gene in different cohorts of patients with vascular anomalies

\begin{tabular}{|c|c|c|c|c|c|}
\hline \multirow[t]{2}{*}{ Author, year } & \multirow[t]{2}{*}{$\begin{array}{l}\text { Familial occurrence, } \\
\text { number of families }\end{array}$} & \multicolumn{2}{|c|}{$\begin{array}{l}\text { Individuals screened for } \\
\text { RASA1 mutations }\end{array}$} & \multirow[t]{2}{*}{$\begin{array}{l}\text { Number of } \\
\text { mutations } s^{d}\end{array}$} & \multirow[t]{2}{*}{ Diagnosis and symptoms } \\
\hline & & All $^{\mathrm{a}}$ & $\begin{array}{l}\text { Symptomatic } \\
\text { allb/mutated }^{\mathrm{c}}\end{array}$ & & \\
\hline $\begin{array}{l}\text { Eerola et al., } \\
2003[1]\end{array}$ & $\begin{array}{c}+ \\
15\end{array}$ & 188 & $86 / 38$ & 6 & $\begin{array}{c}\text { CMs, nauchal CMs, AVMs, } \\
\text { AVFs, PWS }\end{array}$ \\
\hline $\begin{array}{l}\text { Hershkovitz } \\
\text { et al., } 2008 \text { [42] }\end{array}$ & $\begin{array}{l}+ \\
1 \\
\end{array}$ & 3 & $2 / 1$ & 1 & $\begin{array}{l}\text { CMs, limb enlargement, } \\
\text { suggesting PWS or KTWS }\end{array}$ \\
\hline $\begin{array}{l}\text { Wooderchak- } \\
\text { Donahue et al., } \\
2012 \text { [15] }\end{array}$ & $\begin{array}{l}\text { No familial examination } \\
11 \text { individuals with } \\
\text { positive family history, } \\
18 \text { with negative family } \\
\text { history and } 4 \text { with } \\
\text { unknown }\end{array}$ & 33 & $33 / 8$ & 8 & CMs, AVMs, AVFs \\
\hline $\begin{array}{l}\text { de Wijn et al., } \\
2012 \text { [14] }\end{array}$ & $\begin{array}{l}+ \\
1\end{array}$ & 17 & $11 / 11$ & 1 & CMs, AVMs, varicose veins \\
\hline $\begin{array}{l}\text { Durrington } \\
\text { et al., } 2013 \text { [43] }\end{array}$ & $\begin{array}{c}- \\
\text { Case report }\end{array}$ & 1 & $1 / 1$ & 1 & $\begin{array}{l}\text { CM-AVM, CMs, varicose } \\
\text { veins }\end{array}$ \\
\hline $\begin{array}{l}\text { Revencu et al., } \\
2013 \text { [44] }\end{array}$ & $\begin{array}{l}+ \\
68\end{array}$ & 261 & $261 / 68$ & 58 & $\begin{array}{l}\text { CM-AVM (all mutations } \\
\text { have been found only in } \\
\text { this phenotype), CMs, } \\
\text { SWS, AVMs }\end{array}$ \\
\hline $\begin{array}{l}\text { Weitz et al., } \\
2015 \text { [2] }\end{array}$ & $\begin{array}{c}\text { No familial examination, } \\
4 \text { of } 5 \text { tested individuals } \\
\text { have positive family } \\
\text { history }\end{array}$ & 5 & $5 / 4$ & 4 & CMs, AVFs, AVMs \\
\hline $\begin{array}{l}\text { Whitaker et al., } \\
2016 \text { [45] }\end{array}$ & $\begin{array}{c}- \\
\text { Case report }\end{array}$ & 1 & $1 / 1$ & 1 & CMs \\
\hline
\end{tabular}

a Number of all individuals subjected to molecular testing. ${ }^{b}$ Number of individuals subjected to molecular testing with characteristic vascular anomalies listed in the next column. Individuals with vascular anomalies with the presence of mutation in the RASA1 gene. ${ }^{d}$ Number of detected mutations (both novel and previously described). AVMs - arteriovenous malformations, AVFs - arteriovenous fistulas, CMs - capillary malformations, CM-AVM - capillary malformation-arteriovenous malformation syndrome, SWS - Sturge-Weber syndrome, KTWS - Klippel-Trénaunay-Weber syndrome, PWS - Parker Weber syndrome, 't' symbol indicates positive family history, while '- 'symbol presents negative family history.

study, $74 \%$ of patients were diagnosed with hepatic vascular malformations when systematic liver imaging (CT scan) was performed [52]. The other complications of HHT syndrome are anemia and pulmonary hypertension.

Hereditary hemorrhagic telangiectasia, also known as the Osler-Weber-Rendu disease (HHT; OMIM 187300), has an autosomal dominant inheritance pattern, like the other CM-AVM syndromes [53]. While, in fact, RASA1 mutations can cause HHT phenotype, making it part of the CM-AVM syndrome spectrum, current research indicates several other genes involved in HHT development and progress [47, 51]. So far, the reported genes include ENG, ACVRL 1, GDF2 and SMAD4[24, 47, 51, 53-58]. Interestingly, all these genes are members of the same signaling pathway (TGF- $\beta$ ) and apparently, various alterations in this pathway may lead to different variants of the disease (Figure 2) [54, $59,60]$.

The most recognized causative gene for $\mathrm{HHT}$, with a large number of known mutations, is ENG (OMIM 131195) [54, 60-62]. It encodes an auxiliary transmembrane glycoprotein that is responsible for signal transduction [63]. ENG is located in the 9 q34 region. The product of expression (endoglin protein) is a receptor for TGF- $\beta$ signaling proteins [64]. The main function of endoglin is signal modulation between ALK1 and ALK5 receptors that are responsible for the appropriate function of the Smad1/5/8 signaling pathways [63]. Those pathways are related to angiogenesis, the immune system response and cellular proliferation processes $[65,66]$. Higher expression of ENG is noted in tumors [67]. In addition, increased levels of ENG expression accompany wound healing and tissue inflammation in general [68]. It has been established that mutations in ENG correlate with $\mathrm{HHT}$ type 1 [69].

Another gene widely described in the context of HHT is ACVRL1, also known as ALK1 (OMIM 601284). It encodes the anaplastic lymphoma receptor tyrosine kinase $[60,70]$. It was presumed that alterations of this gene may lead to HHT type 2 [71]. The gene is located in region 2p23.2-p23.1. The ACVRL 1 product is a component of the protein complex involved in the interaction with TGF- $\beta$ family signaling proteins [72]. The ACVRL1 


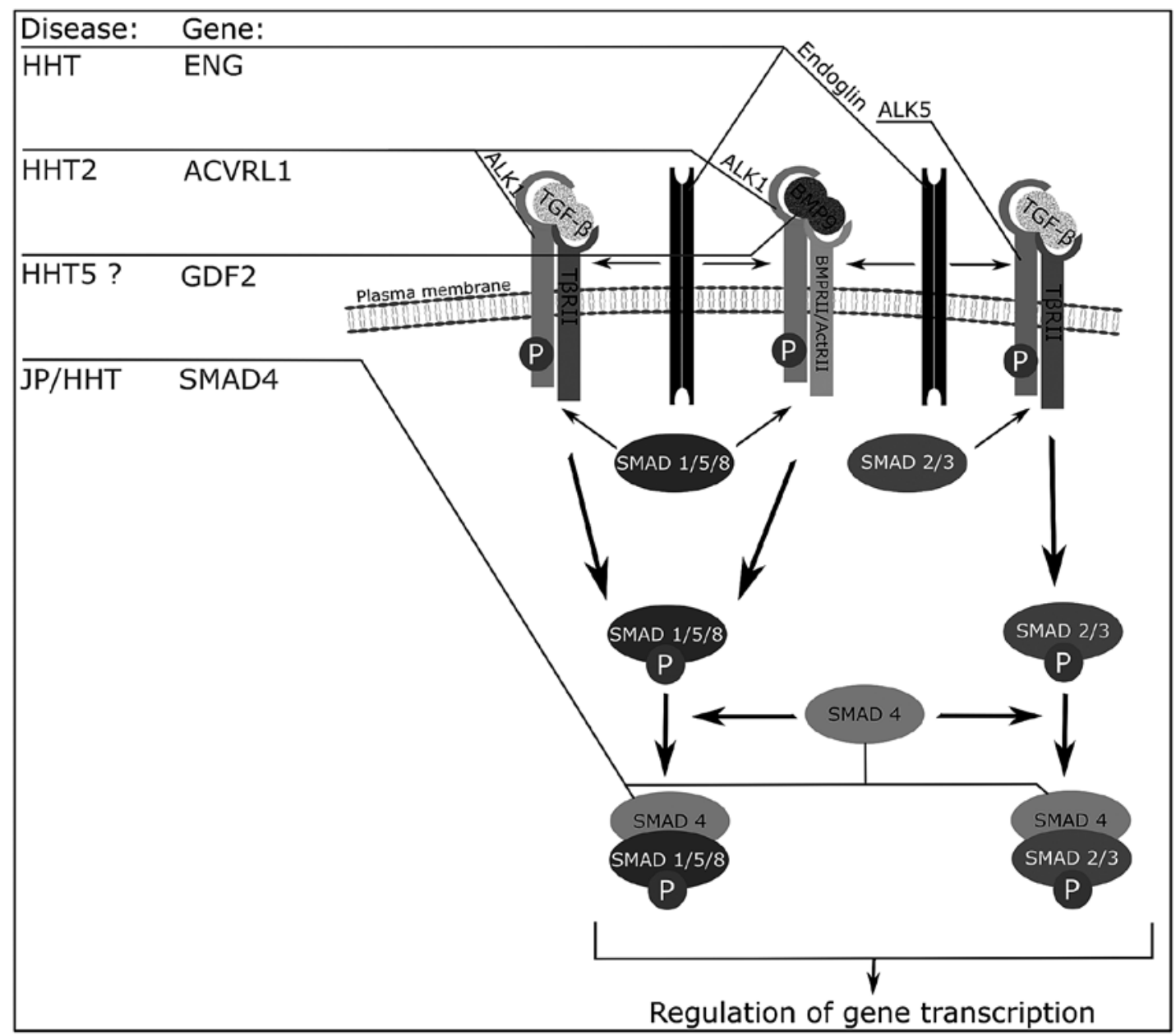

Figure 2. A simplified model of the TGF- $\beta$ signaling pathway. Abnormalities of this cascade may lead to different types of HHT. Several genes are indicated in HHT pathogenesis. Endoglin, the product of ENG gene expression, is responsible for signal modulation between ALK1 and ALK5 receptors. Mutations in ACVRL1 result in faulty interaction of ALK1 with other TGF signaling proteins. BMP9 protein, the product of GDF2, interacts with both ALK1 and endoglin. SMAD4 is involved in later steps of this signaling cascade together with other SMAD proteins. Its malfunction may also lead to HHT $[59,60]$

protein influences signaling pathways similarly as endoglin. Both ENG and ACVRL1 are involved in modulation of the endothelial cell response that is responsible for angiogenesis and vascular development [73]. Several studies concerning the prevalence of mutations of these two genes in various patient cohorts have been published (Table II).

The genetic background of the other HHT types is not well understood. However, it was shown that anomalies of BMP9 protein, a product of the GDF2 gene, may result in HHT type $5[54,74]$. BMP9 was suggested to act as an antimetastatic factor [75]; on the other hand, it may be responsible for survival and intensified proliferation of hepatocellular carcinoma cells [76]. BMP9 interacts with both endoglin and ACVRL1, which explains the HHT phenotype in GDF2 mutations [54, 74].

Another noteworthy gene is SMAD4, which also plays a role in angiogenesis and vascular remodeling as a member of the TGF- $\beta$ signaling pathway
[77]. Studies have demonstrated that mutations in SMAD4 may result in $\mathrm{HHT}$, but also thoracic aortopathy and autosomal dominant cancer predisposition syndrome (juvenile polyposis syndrome - JPS) [78]. These presentations can overlap, as some patients exhibit both typical HHT symptoms and JPS [78, 79]. Because of these ominous co-morbidities, cautious radiological surveillance was suggested in SMAD4 and GDF2 mutation carriers [79-84].

\section{Parkes Weber syndrome}

Parkes Weber syndrome (PWS) is characterized by a cutaneous, red or pink, large, flat patch with underlying quiescent AVMs and extremity overgrowth that affects both bones and soft tissues. It is due to the presence of multiple AVFs along the affected extremity. These AVFs are readily detected by Doppler ultrasound or magnetic resonance angiography [85]. As a rule, the lower extremities are 
Table II. Mutations in ENG and ACVRL1 genes in different cohorts of patients with hereditary hemorrhagic telangiectasia

\begin{tabular}{|c|c|c|c|c|c|}
\hline \multirow[t]{2}{*}{ Author, year } & \multirow[t]{2}{*}{ Analyzed gene } & \multirow{2}{*}{$\begin{array}{l}\text { Number } \\
\text { of screened } \\
\text { sporadic cases } \\
\text { and individuals } \\
\text { with positive } \\
\text { family history }\end{array}$} & $\begin{array}{c}\text { Individuals } \\
\text { screened for } \\
\text { ENG and } A C V R L 1 \\
\text { mutations }\end{array}$ & $\begin{array}{c}\text { Number } \\
\text { of mutations }{ }^{c}\end{array}$ & \multirow[t]{2}{*}{ Clinical diagnosis } \\
\hline & & & $\begin{array}{l}\text { Patients with } \\
\text { mutation }{ }^{\mathrm{a}} / \\
\text { All symptomatic } \\
\text { patients }^{\mathrm{b}}\end{array}$ & & \\
\hline \multirow{2}{*}{$\begin{array}{l}\text { Lesca et al., } \\
2004 \text { [80] }\end{array}$} & $E N G$ & \multirow{2}{*}{$\begin{array}{l}\text { Number of } \\
\text { individuals with } \\
\text { positive family } \\
\text { history not } \\
\text { shown }\end{array}$} & $34 / 160$ & 34 & \multirow[b]{2}{*}{$\begin{array}{l}\text { Each proband } \\
\text { fulfilled at least } \\
\text { three criteria } \\
\text { characteristic for } \\
\text { HHT (epistaxis, } \\
\text { telangiectasias, } \\
\text { visceral lesions, } \\
\text { positive family } \\
\text { history) }\end{array}$} \\
\hline & ACVRL 1 & & $64 / 160$ & 36 & \\
\hline \multirow{2}{*}{$\begin{array}{l}\text { Schulte et al., } \\
2005 \text { [81] }\end{array}$} & $E N G$ & \multirow{2}{*}{$\begin{array}{c}28 \text { sporadic } \\
\text { cases and } 65 \\
\text { individuals with } \\
\text { positive family } \\
\text { history }\end{array}$} & $16 / 63$ & 14 & \multirow[t]{2}{*}{ HHT } \\
\hline & ACVRL 1 & & $18 / 63$ & 16 & \\
\hline \multirow{2}{*}{$\begin{array}{l}\text { Bossler et al., } \\
2006 \text { [82] }\end{array}$} & $E N G$ & \multirow{2}{*}{$\begin{array}{l}121 \text { of } 200 \text { tested } \\
\text { individuals have } \\
\text { positive family } \\
\text { history }\end{array}$} & $77 / 200$ & 63 & \multirow[b]{2}{*}{$\begin{array}{l}\text { Each proband } \\
\text { fulfilled at least } \\
\text { one criterion } \\
\text { characteristic for } \\
\text { HHT (epistaxis, } \\
\text { telangiectasias, } \\
\text { AVMs, positive } \\
\text { family history) }\end{array}$} \\
\hline & ACVRL 1 & & $50 / 200$ & 40 & \\
\hline \multirow{2}{*}{$\begin{array}{l}\text { Olivieri et al., } \\
2007 \text { [83] }\end{array}$} & $E N G$ & \multirow{2}{*}{$\begin{array}{l}123 \text { of } 137 \text { tested } \\
\text { individuals have } \\
\text { positive family } \\
\text { history, other } \\
\text { cases were } \\
\text { characterized as } \\
\text { sporadic }\end{array}$} & $29 / 137$ & 26 & \multirow[t]{2}{*}{$\mathrm{HHT}$} \\
\hline & ACVRL 1 & & $72 / 137$ & 50 & \\
\hline $\begin{array}{l}\text { Plumitallo } \\
\text { et al., } 2018 \text { [84] }\end{array}$ & ENG & $\begin{array}{l}\text { All individuals } \\
\text { belong to one } \\
\text { family }\end{array}$ & $3 / 3$ & 1 & HHT \\
\hline
\end{tabular}

a Number of symptomatic individuals subjected to molecular testing. ${ }^{b}$ Individuals with mutation in specific gene. ${ }^{c}$ Number of detected mutations (both novel and previously described). HHT - hereditary hemorrhagic telangiectasia, AVMs - arteriovenous malformations.

more often affected than the upper extremities. The AVFs usually develop in adolescence, spontaneously or after trauma, including any surgical procedures on the affected limb. The VMs are usually present from childhood. The angiogram reveals areas of hypervascularization with enlarged vessels. Common life-threatening complications in PWS include bleeding and congestive heart failure [86].

RASA1 mutations are frequently described in patients with prior diagnosis of PWS. Several authors have reported on patients with atypical, multifocal CMs and findings suggestive of PWS, who had a detectable RASA1 mutation [1-3, 15]. However, a recent study has shown that symptoms typical for PWS combined with AVM may occur without alterations of RASA1 [87]. In fact, patients with PWS without CMs are unlikely to have a mutation in RASA1 [26]. Overall, RASA1 mutations account for about $12 \%$ of PWS causes $[1,15,26]$.

The genetic background of PWS without CMs currently remains unknown. A specific autosomal dominant mutation of the AGGF1 gene, c.397G >A, p.Glu133Lys, has been suggested as a putative causal factor for PWS [88]. In addition, it is believed that alterations in genes that are members of PI3K may lead to some sporadic cases of PWS [89]. Little is known about the actual inheritance pattern and exact incidence of this disease.

\section{Cerebral cavernous malformation}

Cerebral cavernous malformations (CCMs; OMIM 116860) are VMs ominously localized within the central nervous system. It is estimated that CCMs 
are present in $0.5 \%$ of the population worldwide. The thin-walled capillaries of CCMs are prone to traumatic rupture due to the lack of elastic fiber support. Cerebral cavernous malformations can remain clinically silent or be symptomatic. When symptomatic, CCMs present with headache, seizures and focal neurological deficits. Intracranial hemorrhage may occur. Unlike AVMs, CCMs are low flow malformations and are thus notoriously undetectable in angiography. Sometimes, computed tomography reveals calcifications within the vascular lesions, but the study of choice is magnetic resonance imaging $[90,91]$.

So far, research on molecular causes of CCMs has revealed three genes associated with this disorder: KRIT1, CCM2 (MGC4607) and PDCD10, which are located in 7q21s.2,7p13 and 3q26.1, respectively [92]. The KRIT1 (Krev interaction trapped 1) gene was identified in CMM type 1, CCM2 (malcavernin) mutations have been described in CCM type 2 and CCM3 (PDCD10) gene mutations in CCM type 3 (Figure 3) [93-98]. It has been proved by several authors that these three genes play a key role in mechanisms related to vascular development and angiogenesis. A summary of KRIT1, MGC4607 and $P D C D 10$ mutation screening studies in CCM is presented in Table III.

The products of these genes are auxiliary membrane proteins that cooperate to secure the interaction between endothelial cells in order to prevent blood leakage [99, 100]. Stockton et al. demonstrated that KRIT1 and CCM2 are suppressors of the signaling protein RhoA [97, 101]. They inhibit the activity of Rho kinase (ROCK), a RhoA effector, in order to stabilize and strengthen the intercellular interactions of the endothelial cells. The RhoA/Rho kinase pathway is responsible for cell contraction and migration, and it also supports cellular adherence by controlling the cytoskeletal organization $[99,102,103]$. The KRIT1 migrates from the nucleus to the cytosol to recruit the elements necessary for cell-cell junctions [99, 104]. The CCM2 protein is responsible for transportation of KRIT1 from the nucleus to the cytosol. Depletion of CCM2 disrupts the translocation of KRIT1 [105]. CCM2 binds to E3 ubiquitin ligase (Smurf1), decreasing the expres-

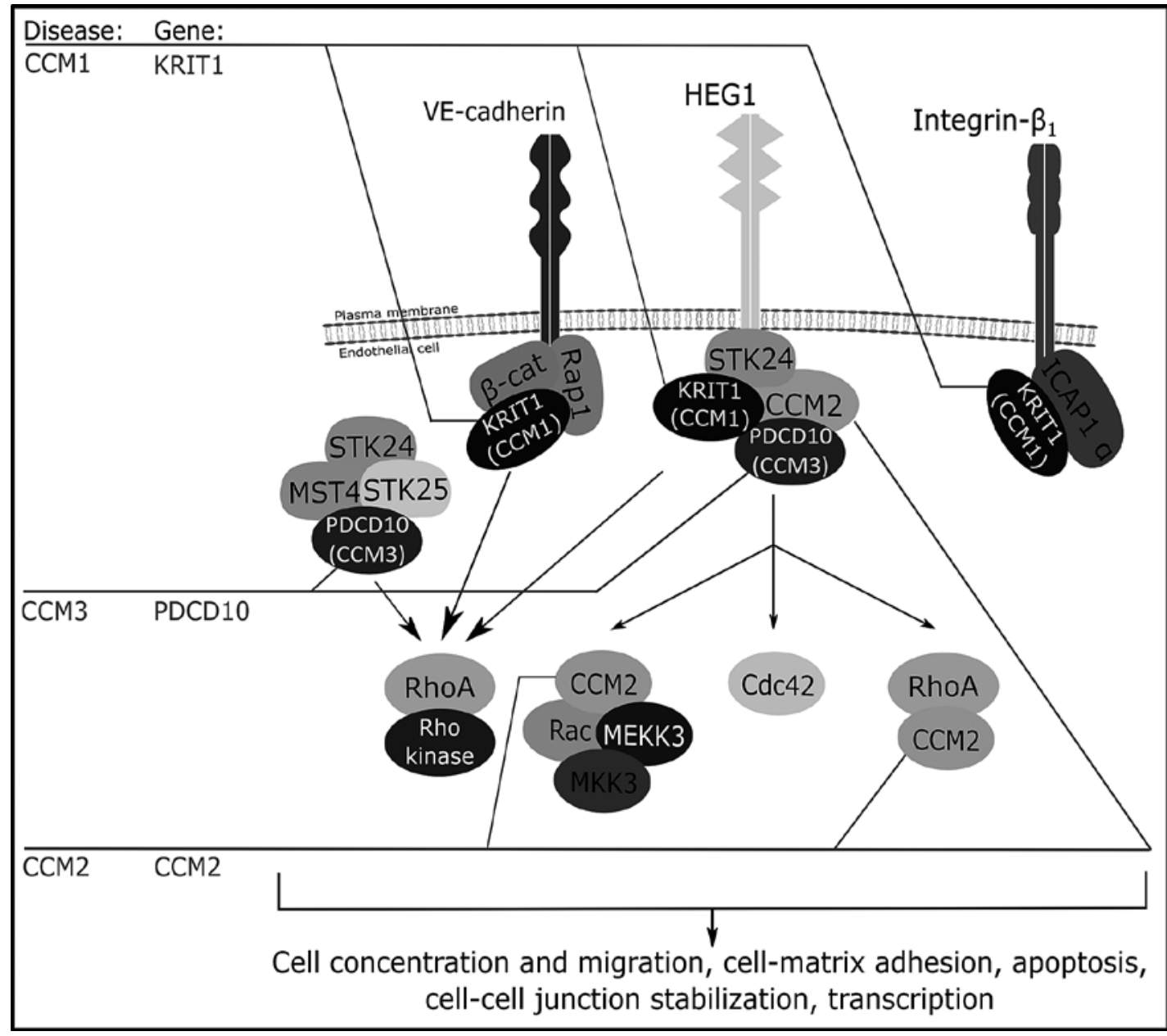

Figure 3. A model of CCMs related proteins' interaction with VE-cadherin, HEG1 and integrin- $\beta_{1}$. They are responsible for coupling of extracellular and intracellular signaling pathways. Alterations in KRIT1, PDCD10 and CCM2 may lead to CCMs type 1, 3 and 2, respectively $[97,98]$ 
Table III. Mutations in KRIT1, MGC4607 and PDCD10 genes in different cohorts of patients with cerebral cavernous malformations

\begin{tabular}{|c|c|c|c|c|c|}
\hline \multirow[t]{2}{*}{ Author, year } & \multirow[t]{2}{*}{$\begin{array}{l}\text { Analysed } \\
\text { gene }\end{array}$} & \multirow{2}{*}{$\begin{array}{l}\text { Number of } \\
\text { screened spo- } \\
\text { radic cases and } \\
\text { individuals with } \\
\text { positive family } \\
\text { history }\end{array}$} & $\begin{array}{l}\text { Individuals screened for KRIT1, } \\
M G C 4607 \text { and } P D C D 10 \text { mutations }\end{array}$ & \multirow{2}{*}{$\begin{array}{l}\text { Number } \\
\text { of muta- } \\
\text { tions }^{3}\end{array}$} & \multirow{2}{*}{$\begin{array}{l}\text { Criteria for } \\
\text { molecular } \\
\text { testing }\end{array}$} \\
\hline & & & $\begin{array}{l}\text { Patients with mutation }{ }^{1 /} \\
\text { All symptomatic patients }{ }^{2}\end{array}$ & & \\
\hline \multirow{3}{*}{$\begin{array}{l}\text { Stahl et al., } \\
2008[116]\end{array}$} & KRIT1 & \multirow{3}{*}{$\begin{array}{l}16 \text { individuals } \\
\text { with positive } \\
\text { family history } \\
\text { (mutation found } \\
\text { in } 15 \text { ) } \\
12 \text { sporadic } \\
\text { cases } \\
\text { (mutation found } \\
\text { in } 8 \text { ) }\end{array}$} & $14 / 28$ & 14 & \multirow{3}{*}{$\begin{array}{c}\text { Multiple } \\
\text { lesions } \\
\text { (sporadic } \\
\text { cases and } \\
\text { cases with } \\
\text { positive family } \\
\text { history) }\end{array}$} \\
\hline & MGC4607 & & $8 / 28$ & 28 & \\
\hline & PDCD10 & & $1 / 28$ & 1 & \\
\hline $\begin{array}{l}\text { Cigoli et al., } \\
2014 \text { [117] }\end{array}$ & PDCD10 & $\begin{array}{l}\text { Exact number of } \\
\text { individuals with } \\
\text { positive family } \\
\text { history not } \\
\text { shown }\end{array}$ & $11 / 87$ & 8 & $\begin{array}{l}\text { At least one } \\
\text { affected } \\
\text { relative and/o } \\
\text { multiple CCMs }\end{array}$ \\
\hline \multirow{3}{*}{$\begin{array}{l}\text { Mondéjar } \\
\text { et al., } 2014 \\
{[118]}\end{array}$} & KRIT1 & \multirow{3}{*}{$\begin{array}{l}231 \text { individuals } \\
\text { with positive } \\
\text { family history } \\
\text { (mutation found } \\
\text { in } 65 \text { ) } \\
41 \text { sporadic } \\
\text { cases } \\
\text { (mutation found } \\
\text { in 19) }\end{array}$} & $53 / 254$ & 20 & \multirow{3}{*}{$\begin{array}{c}\text { At least one } \\
\text { affected } \\
\text { relative and/o } \\
\text { multiple CCMs }\end{array}$} \\
\hline & MGC4607 & & $26 / 254$ & 7 & \\
\hline & PDCD10 & & $5 / 254$ & 4 & \\
\hline \multirow{3}{*}{$\begin{array}{l}\text { Spiegler et al., } \\
2014 \text { [112] }\end{array}$} & KRIT1 & \multirow{3}{*}{$\begin{array}{c}63 \text { familial cases } \\
\text { (mutation found } \\
\text { in } 55 \text { ) } \\
42 \text { sporadic } \\
\text { cases } \\
\text { (mutation found } \\
\text { in } 24 \text { ) }\end{array}$} & $48 / 105$ & 30 & \multirow{3}{*}{$\begin{array}{c}\text { Multiple } \\
\text { lesions in } \\
\text { sporadic case } \\
\text { or in patients } \\
\text { with positive } \\
\text { family history }\end{array}$} \\
\hline & MGC4607 & & $14 / 105$ & 5 & \\
\hline & PDCD10 & & $17 / 105$ & 12 & \\
\hline $\begin{array}{l}\text { Cigoli et al., } \\
2015 \text { [119] }\end{array}$ & MGC4607 & $\begin{array}{l}6 \text { individuals } \\
\text { from one family }\end{array}$ & $5 / 5$ & 1 & $\begin{array}{c}\text { Multiple } \\
\text { lesions and } \\
\text { positive family } \\
\text { history }\end{array}$ \\
\hline \multirow{3}{*}{$\begin{array}{l}\text { Hirota et al., } \\
2016[120]\end{array}$} & KRIT1 & \multirow{3}{*}{$\begin{array}{l}12 \text { individuals } \\
\text { with positive } \\
\text { family history } \\
\text { (from three } \\
\text { different } \\
\text { families) have } \\
\text { been tested }\end{array}$} & $5 / 6$ & 3 & \multirow{3}{*}{$\begin{array}{c}\text { CCMs and } \\
\text { spinal } \\
\text { cavernous } \\
\text { malformations } \\
\text { diagnosed } \\
\text { using MRI }\end{array}$} \\
\hline & MGC4607 & & $0 / 6$ & 0 & \\
\hline & PDCD10 & & $0 / 6$ & 0 & \\
\hline \multirow{3}{*}{$\begin{array}{l}\text { Scimone et al., } \\
2017 \text { [111] }\end{array}$} & KRIT1 & \multirow{3}{*}{$\begin{array}{l}4 \text { individuals } \\
\text { with positive } \\
\text { family history, } \\
12 \text { sporadic } \\
\text { cases where } \\
3 \text { manifest } \\
\text { multiple lesions }\end{array}$} & $6 / 7$ & 2 & \multirow{3}{*}{$\begin{array}{c}\text { Multiple } \\
\text { lesions and } \\
\text { positive family } \\
\text { history }\end{array}$} \\
\hline & MGC4607 & & $3 / 7$ & 1 & \\
\hline & PDCD10 & & $0 / 7$ & 0 & \\
\hline $\begin{array}{l}\text { Yang et al., } \\
2017[121]\end{array}$ & KRIT1 & $\begin{array}{l}21 \text { individuals } \\
\text { from } 5 \text { families }\end{array}$ & $7 / 12$ & 0 & Multiple CCMs \\
\hline
\end{tabular}

${ }^{1}$ Number of symptomatic individuals subjected to molecular testing. ${ }^{2}$ Individuals with mutation in specific gene. ${ }^{3}$ Number of detected mutations (both novel and previously described). CCMs - cerebral cavernous malformations, MRI-magnetic resonance imaging. 
sion of RhoA [101]. CCM3 (OMIM 609118) encodes a protein that interacts with $\mathrm{CCM} 2$ and serine/ threonine kinase 25 (STK25), to form a three-protein complex which may be essential for vascular development. It was suggested that its inactivation may initiate CCM formation [106]. The main function of PDCD10 might be the promotion of cell apoptosis [107, 108]. The PDCD10 gene expression product has a significant role in RhoA activation $[109,110]$. Loss of the aforementioned protein has also been described in the context of neuronal development where it was linked to cytoskeleton defects [110]. The incidence of mutations in KRIT1, CCM2 and PDCD 10 in CCMs is 56\%, 16\% and $17 \%$ respectively [111, 112].

Regarding deletions in genes mentioned above, the distribution appears to differ among patients of different origins. When two cohorts of patients were tested using multiplex ligation-dependent probe amplification technique, it was found that proportions of deletions for KRIT1, CCM2 and $P D C D 10$ in an American group of patients were $5 \%, 95 \%$ and $0 \%$, while the distribution in Italians was $50 \%, 40 \%$ and $10 \%$ respectively [113]. Genomic rearrangements of the region including CCM2 are a suspected cause of familial CCMs as well [114]. Another novel putative mechanism of CCM pathogenesis is related to polymorphisms of TLR4 and CD14 genes. It has been suggested that their activation due to Gram-negative bacteria may accelerate the development of CCMs [115-121].

\section{Glomuvenous malformation}

Glomuvenous malformations (GVMs, OMIM 13800), often described as glomangiomas or "venous malformations with glomus cells", should be distinguished from mucocutaneous cavernous hemangiomas. The GVMs are commonly present at birth or appear during the first two decades of life. The hallmark features of the GVMs are their cobblestone appearance, hard consistency and tenderness. The histopathology examination shows pathognomonic rounded cells (glomus cells) around the blood-filled cavities. The glomus cells stain positively for smooth-muscle $\alpha$-actin and vimentin, which suggests their muscular origin [122]. It is claimed that glomus cells may be incorrectly or incompletely differentiated vascular smooth muscle cells [122].

The occurrence of glomuvenous malformations (GVMs) was found to be associated with mutations in the GLMN gene (OMIM 601749), which is located in region $1 \mathrm{p} 22[123,124]$. The product of GLMN, glomulin, is a competitive inhibitor of a group of ubiquitin ligases (E3s), cullin-RING ligases (CRLs; Figure 4). These multisubunit enzymes contain one of two types of RING protein, RBX1 or RBX2, by which they interact with a ubiquitin-conjugating enzyme (E2) to complete ubiquitination. Glomulin binds to the RING domain of RBX1, acting as a regulator of ubiquitination by preventing the E2 accession to the SCF complex, and thus by inhibiting the E3 ligase activity. While the RING E3 ligase subunit of CRL may contain either RBX1 or RBX2, it appears that glomulin's tri-HEAT-like platform binds exclusively to RBX1's E2-interacting surface. The regulation of $C R L$ by glomulin is responsible for ubiquitination of many proteins, including ones that are important for proper vascular development [125-129]. Interestingly, McIntyre et al. observed an increased level of expression of GLMN in vascular smooth muscle cells in mice, suggesting globulin's ubiquitous involvement in numerous processes [130-133].

A

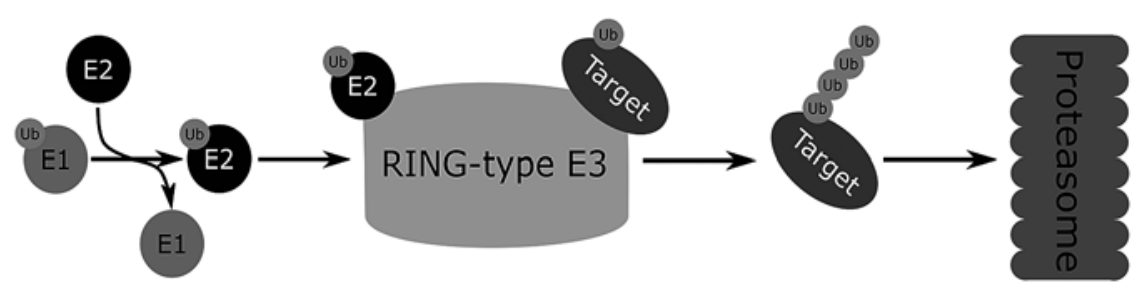

B Disease: Gene:

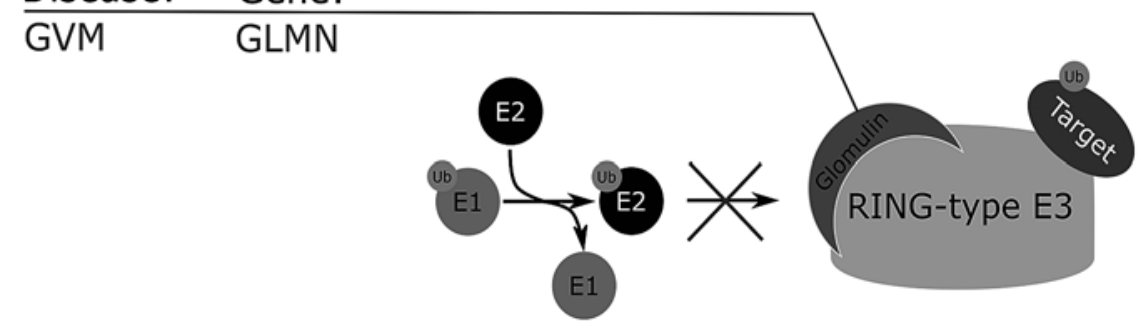

Figure 4. A - A simplified model of protein ubiquitination by RING-type E3 enzyme. The ubiquitination of target protein is completed by interaction with a ubiquitin-conjugating enzyme (E2). B - Due to glomulin binding to E3, E2 accession to the complex is prevented and the entire process is inhibited. Mutations of GLMN prevent inhibition of ubiquitination. This may lead to development of GVMs [125, 131-133] 
In 1998 it was established that GVMs have an autosomal dominant inheritance pattern with $100 \%$ penetrance by the age of 30 years [134]. Further studies have indicated that penetrance is almost complete 10 years earlier, reaching $97.2 \%$ by 20 years [122]. Between 38 and $63.8 \%$ of cases of GVMs are inherited [135-137]. Published sources indicate that numerous GLMN variants are responsible for the disease [138]. Among $162 \mathrm{kin}$ dreds reported by Brouillard et al., the premature stop mutation which leads to truncation of the protein (c.157_161del, p.(Lys53*)) was the most frequent, making up almost half of the cases. Additionally, only 19 individuals in which the mutations had been found were considered sporadic $[138,139]$. Several other studies dealing with molecular screening of GLMN in patients with GVMs were performed (Table IV) [140, 141]. In addition to GLMN mutations sensu stricto, Ohata et al. also found a region with loss of heterozygosity $(\mathrm{LOH})$ near the GLMN gene [139]. So far no other genes have been associated with this disease.

\section{Venous malformations, multiple cutaneous and mucosal}

The characteristic features of venous malformations, multiple cutaneous and mucosal (OMIM 600195 , VMCMs) are multiple small venous malformations, including cavernous hemangiomas, located in any part of the body, mostly affecting the internal organs. The coincidence of additional abnormalities such as cardiac malformations (e.g. ventricular septal defects) has been reported. Venous malformations are found on the skin of the limbs and trunk, on mucosal surfaces (on lips, tongue and tonsils, in the larynx, stomach and large intestine) and in viscera, including the liver, pancreas and spleen. On the skin and mucosa, the typical lesions are small, multifocal, bluish vascular malformations. Bleeding may occur [142].

Histopathological examination shows ectatic and relatively thin vessels, lined with one layer of endothelial cells without surrounding smooth muscle cells or elastic tissue. The lack of mural cells may suggest a recruitment defect $[143,144]$. VMCMs are associated with mutations in the TEK gene (protein receptor tyrosine kinase, epithelial specific; OMIM 600221), also known as TIE2, and are inherited in an autosomal dominant manner [20]. The TEK tyrosine kinase receptor interacts with ANGPT1, ANGPT2 and ANGPT4 (Figure 5) [145]. Interaction with ANGPT1 triggers many signaling pathways and cascades by AKT1 activation [146]. The activation of the AKT1 enables communication between endothelial cells and smooth muscle cells and stimulates appropriate angiogenesis [147]. It is widely accepted that TIE2/TEK is mandatory for the proper development of the vascular system and plays an important role in angiogenesis and vascular stability [148-151].

Wouters et al. found a mutation in the TEK gene (c.2545C >T, p.Arg849Trp) in 14 individuals out of 26 patients with VMCMs. The identified mutation affects an intracellular domain of the TEK protein [143]. It has been suggested that specific functional abnormalities depend on the type of mutation [152]. In gain-of-function mutations of TEK, there is an increase in autophosphorylation and subsequent activation of the STAT1 signaling pathway $[148,152,153]$. On the other hand, a loss of function mutation was also found in a tissue sample from an VMCM affected individual [148].

Table IV. Mutations in GLMN (glomulin) gene in different cohorts of patients with glomuvenous malformations

\begin{tabular}{|c|c|c|c|c|c|}
\hline \multirow[t]{2}{*}{ Author, year } & \multirow{2}{*}{$\begin{array}{l}\text { Number of families } \\
\text { and screened individuals } \\
\text { with positive family history }\end{array}$} & \multicolumn{2}{|c|}{$\begin{array}{l}\text { Individuals screened } \\
\text { for } G L M N \text { mutations }\end{array}$} & \multirow[t]{2}{*}{$\begin{array}{l}\text { Number of } \\
\text { mutations }{ }^{d}\end{array}$} & \multirow{2}{*}{$\begin{array}{l}\text { Criteria for } \\
\text { molecular } \\
\text { testing }\end{array}$} \\
\hline & & All $^{a}$ & $\begin{array}{l}\text { Symptomatic allb/ } \\
\text { mutated }^{\mathrm{c}}\end{array}$ & & \\
\hline $\begin{array}{l}\text { Brouillard } \\
\text { et al., } 2002 \\
{[122]}\end{array}$ & $\begin{array}{c}238 \text { individuals from } \\
20 \text { families tested, mutations } \\
\text { found in each family, and one } \\
\text { sporadic case }\end{array}$ & $\begin{array}{l}238+1 \\
\text { sporadic }\end{array}$ & $\begin{array}{c}110+1 \text { sporadic/ } \\
110+1 \text { sporadic } \\
\text { (additionally } \\
15 \text { unaffected carriers } \\
\text { tested) }\end{array}$ & 14 & $\begin{array}{l}\text { Multiple } \\
\text { GVMs and } \\
\text { also VMs }\end{array}$ \\
\hline $\begin{array}{l}\text { Brouillard } \\
\text { et al., } 2005 \\
{[140]}\end{array}$ & $\begin{array}{l}52 \text { individuals from } \\
23 \text { families tested, mutations } \\
\text { found in each family }\end{array}$ & 53 & $\begin{array}{c}42 / 42 \\
\text { (additionally } 5 \text { unaffected } \\
\text { carriers tested) }\end{array}$ & 17 & $\begin{array}{l}\text { Multiple } \\
\text { GVMs }\end{array}$ \\
\hline $\begin{array}{l}\text { O'Hagan et al., } \\
2006 \text { [141] }\end{array}$ & $\begin{array}{l}36 \text { individuals from } \\
4 \text { families tested }\end{array}$ & 36 & $19 / 19$ & 1 & $\begin{array}{l}\text { Multiple } \\
\text { GVMs }\end{array}$ \\
\hline $\begin{array}{l}\text { Brouillard } \\
\text { et al., } 2013 \\
{[138]}\end{array}$ & $\begin{array}{l}381 \text { individuals from } \\
162 \text { families tested }\end{array}$ & 465 & $\begin{array}{c}344 / 344 \\
\text { (additionally } \\
37 \text { unaffected carriers } \\
\text { tested) }\end{array}$ & 40 & $\begin{array}{l}\text { GVMs, VMs } \\
\text { and BRBN }\end{array}$ \\
\hline
\end{tabular}

a Number of all individuals subjected to molecular testing. ${ }^{b}$ Number of individuals subjected to molecular testing with diagnosed GVMs. cIndividuals with diagnosed GVMs and with mutation in GLMN gene. ${ }^{\circledR}$ Number of detected mutations (both novel and previously described). GVMs - glomuvenous malformations, VMs - vascular malformations, BRBNS - blue rubber bleb nevus syndrome. 


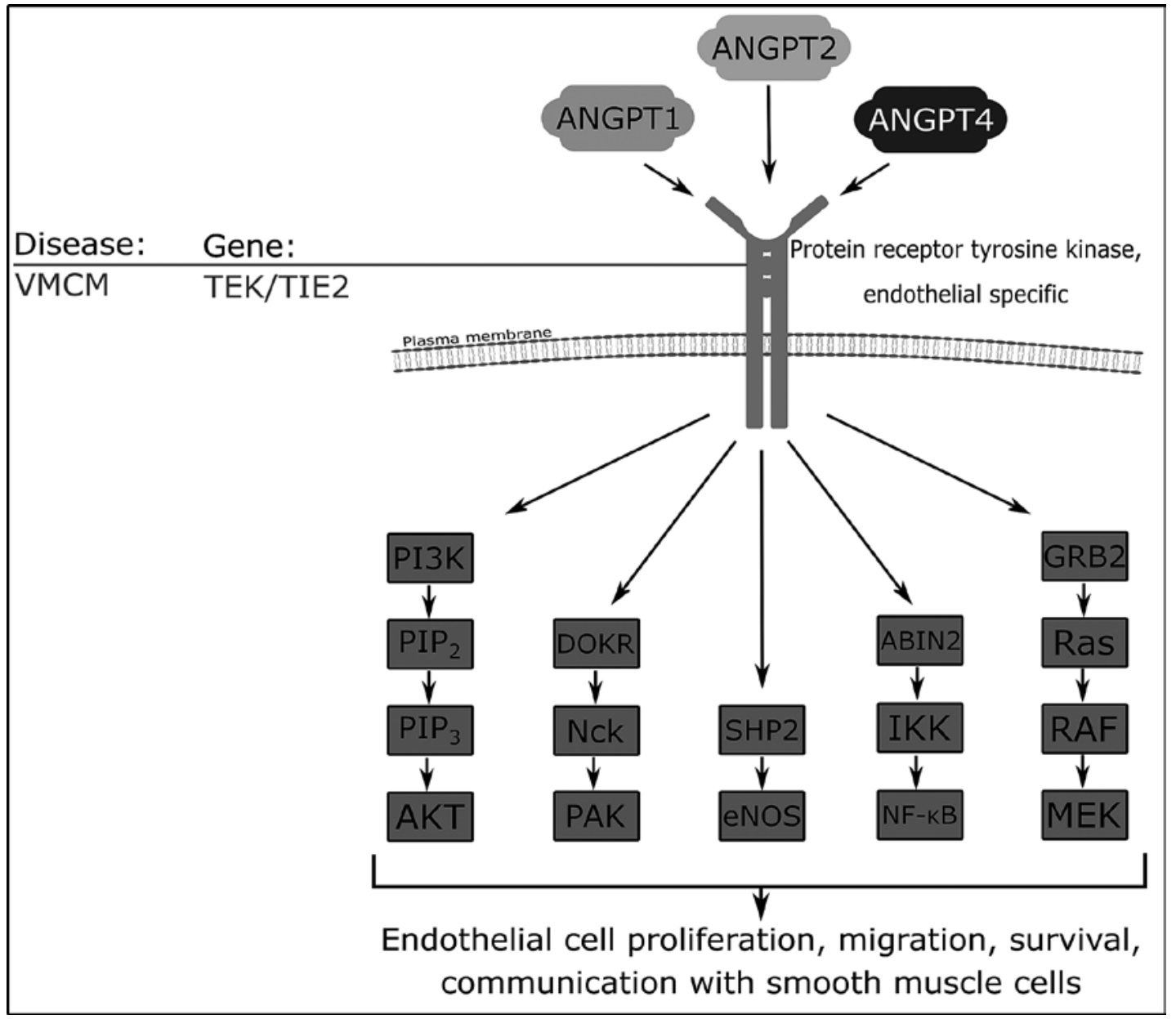

Figure 5. Interactions among ANGPT1, ANGPT2, ANGPT4 and Tie2. Several signaling pathways are triggered by this activation. The most important one in the context of vascular development is PI3K/AKT/mTOR with its numerous subsequent cascades. Alterations of TEK/TIE2 were demonstrated to result in VMCMs. This might suggest that VM has a genetic background similar to VMCMs [151]

\section{Sturge-Weber syndrome}

Sturge-Weber syndrome (SWS) is one of the most widely known capillary malformation syndromes. The hallmark of SWS is the characteristic facial capillary malformation (port-wine stain) coupled with an intracranial malformation, spanning the meninges on the same side. The meningeal malformations are leptomeningeal angiomata that are mostly situated over occipital and posterior parietal lobes. Laminar cortical necrosis and calcification develop due to stasis and ischemia of the neighboring leptomeningeal angiomatosis [154]. The cutaneous manifestation of SWS is the port-wine stain [155]. This birthmark develops in the distribution of one of the branches of the trigeminal nerve, most commonly $\mathrm{V} 1$, the ocular nerve [155]. Bilateral or unilateral port-wine stains involving the branches V1, V2, V3 of the trigeminal nerve and the port-wine stains on the eyelids have a high probability of eye and CNS vascular malformation co-occurrence [156]. Ocular vascular malformations involving the choroidal vessels frequently occur in SWS and lead to glaucoma, buphthalmia and hemianopsia. The clinical presentation of SWS is that of intellectual disability, seizures and focal neurological signs in an individual with a distinct facial birthmark [157]. The clinical course is variable: the seizures may become intractable and recurrent stroke-like episodes may occur. The prevalence of SWS is estimated at 1/20,000-1/50,000.

Curiously, SWS appears to be congenital but not heritable. This, together with strikingly segmental distribution of anomalous tissue, raised a suspicion that SWS may be caused by an acquired, somatic mutation at an early developmental stage, resulting in a chimeric individual with affected cell populations determined to develop the malformations. This elegant theory found support in subsequent research. In 2002, Huq et al. described a $4 \mathrm{q}$ inversion and trisomy of the $10^{\text {th }}$ chromosome, which were present in leptomeningeal angiomatosis tissue sample but not in cells cultured from blood and skin of affected individuals [158]. Recently, the genetic origin of SWS was 


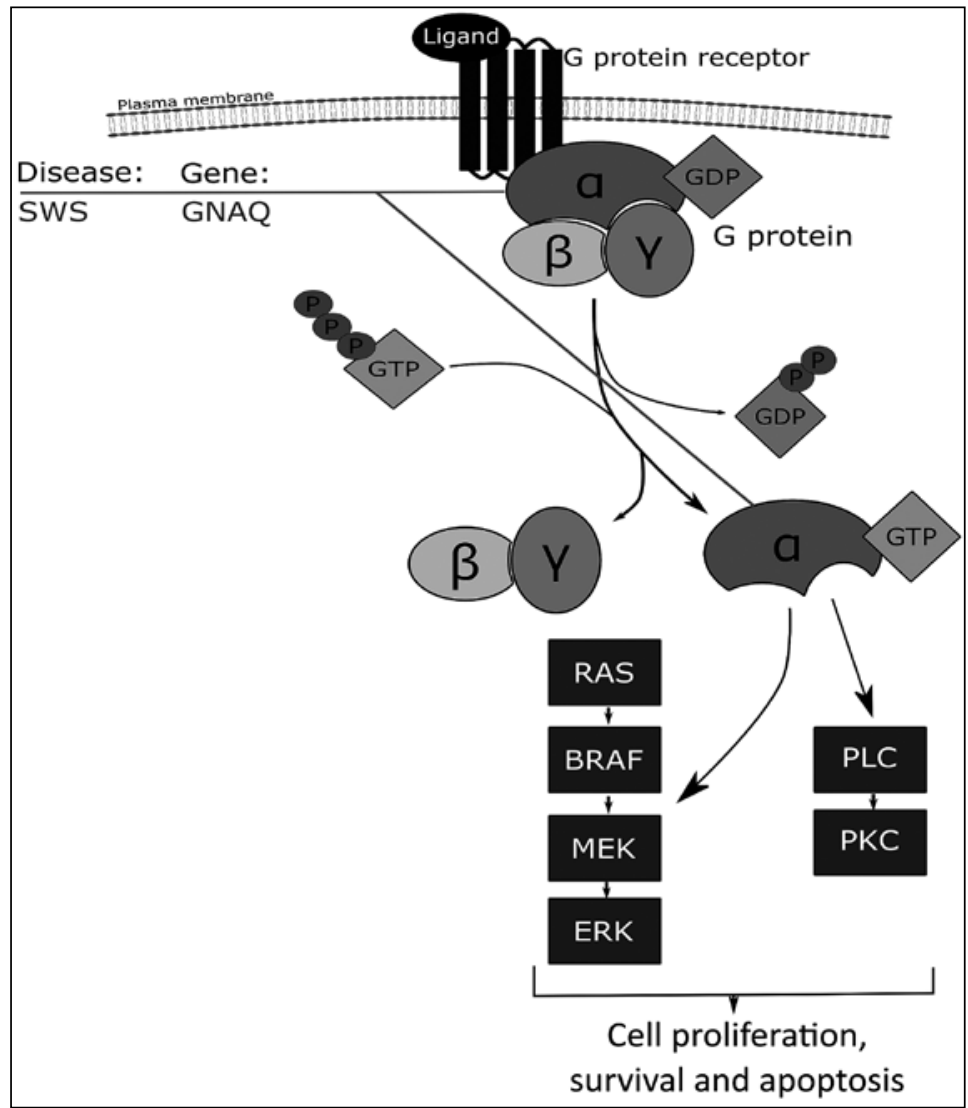

Figure 6. A model for $G$ protein activity and its role in triggering of RAS-MEK-ERK and phospholipase $C$ pathways. The external signal causes activation of $G$ protein by exchanging a GDP particle bound to the G protein for a GTP. The $\alpha$ subunit of G protein (a GNAO expression product) is then released and activates enzymes and effector proteins involved in signaling pathways necessary for vascular development. Alterations of GNAQ are indicated in SWS pathogenesis [159, 164, 165]

further elucidated. In 2013 Shirley et al. identified a single nucleotide variant, i.e. a missense variant (c.548G >A, p.Arg183Gln) in the GNAQ gene within malformed tissue from SWS and nonsyndromic (isolated) port-wine stain, but neither in the patients' unaffected tissue nor healthy controls and unrelated vascular malformations. This particular variant was reported consistently by several other researchers [159-162], with high prevalence of approximately $90 \%$ in pathological samples from SWS and nonsyndromic port-wine stains alike ( $88 \%$ in 23 of 26 patients and $92 \%$ in 12 of 13 patients, respectively $[159,160])$.

The GNAQ (G protein subunit $\alpha$ q; OMIM $600998)$ is located in the $9 q 21.2$ region. The gene encodes an $\alpha$ subunit of guanine nucleotide binding protein, commonly known as $\mathrm{Gq}$ protein. This protein family is involved in important signaling pathways, such as RAS/MAPK, that are significant for cell proliferation, survival and apoptosis [163]. The $\alpha$ domain in inactive form binds to the 7-transmembrane domain receptor. After receiving an external signal, the $\mathrm{Gq} \alpha$ domain turns into an active form by converting the GDP form to the GTP form. The active $\alpha$ domain activates other enzymes and effector proteins that trigger further signaling pathways [164]. Activating mutations of GNAQ may influence pathways such as RAS-MEKERK and phospholipase C (Figure 6) [149, 165]. The GNAQ expression product activates phospholipase $C$ that causes phospholipid cleaves typical forr SWS [147]. the aforementioned mutation, c.548G >A, p.Arg183Gln, destabilizes an inactive GDP-bound conformation of the encoded protein, and thus causes overactivation of the protein and subsequently involved pathways.

The exact developmental stage at which the mutation occurs is not known. Uchiyama et al. demonstrated low prevalence somatic mutations in GNAQ in patients with SWS by using deep sequencing methods [166]. In this study the GNAQ mutation (again, C.548G>A, p.Arg183Gln) was identified in brain lesions, saliva and blood leukocytes. The authors suggested that GNAQ somatic mutation derives from a hemangioblast or an early endothelial cell. They claimed that cells harboring the mutation in blood leukocytes and saliva lymphocytes might actively seed the SWS lesions. Moreover, the latest research by Couto et al. revealed another two variants (both substitutions) of GNAQ (c.548G >T, p.Arg183Leu and c.547C>G, p.Arg183Gly), which were present at a low level 
exclusively in tissue with capillary malformation $[167,168]$. On the other hand, Sundaram et al. suggested that the variation p.Arg183Gln, which is the most common alteration in SWS, is not only linked with vascular malformations, but may also affect brain parenchyma, which could explain the brain pathology present in SWS [169, 170]. In addition to this, in several other studies an attempt to reveal the genetic background of SWS was made, including molecular screening (Table V). Published sources also indicate that mutation in GNA11 may also be responsible for capillary malformations due to the likely close association between this gene and GNAQ [167]. What is more, it has been observed that mutations in those two genes occur in tumors including melanomas [171-173]. Another activating mutation of GNAQ (c.626A $>$ T; p.Gln209Leu) has been reported in SWS, phakomatosis pigmentovascularis (a similarly sporadic condition combining port-wine stain and pigmentary lesion) but also in uncomplicated, congenital hemangiomas and in several melanocytic neoplasms and malignant intraocular tumors including uveal melanomas [160, 174-177].

\section{PIK3CA related syndromes: congenital lipomatous overgrowth with vascular, epidermal, and skeletal anomalies, fibroadipose hyperplasia, megalencephaly- capillary malformation}

Congenital lipomatous overgrowth with vascular, epidermal, and skeletal anomalies (CLOVES syndrome) belongs to segmental or patchy overgrowth syndromes. The symptoms associated with
CLOVES syndrome are progressive and complex. They involve VMs (capillary, arteriovenous, venous and lymphatic), abnormal adipose tissue distribution that may form lipomatous masses, varying degrees of scoliosis, overgrowth of bony tissue with bony distortion in areas that had undergone trauma or major surgical procedures [178].

Recently, the genetic cause of CLOVES syndrome has been identified. An activating somatic mutation in the PIK3CA gene (phosphatidylinositol-4,5-bisphosphate 3-kinase catalytic subunit $\alpha$ ), a component of the PI3K-AKT pathway, is a plausible cause of CLOVES syndrome [179-181]. However, the studies suggest that several other diseases may be caused by PIK3CA mutations. These include PIK3CA-related overgrowth spectrum (PROS), fibroadipose hyperplasia or overgrowth (FAO), hemihyperplasia-multiple lipomatosis syndrome $(\mathrm{HHML})$, macrodactyly and muscle hemihypertrophy, the related megalencephaly syndromes, megalencephaly-capillary malformation (MCAP), hemimegalencephaly as well as an array of neoplasms including colorectal, ovary, breast, lung and brain tumors [178, 180-190].

Fibroadipose hyperplasia (FAH) features overlap with CLOVES syndrome and are characterized by segmental overgrowth of skeletal, visceral, fibroadipose, subcutaneous and muscular tissues with muscle lipomatous infiltration, accompanied by adipose tissue dysregulation and regional lipohypoplasia. Typically disproportionate linear overgrowth is present. Additional findings in $\mathrm{FH}$ may include vascular malformations, epidermal nevi, polydactyly and testicular or epididymal cysts and

Table V. Somatic mutations in GNAQ gene in different cohorts of patients with Sturge-Weber syndrome

\begin{tabular}{|c|c|c|c|c|}
\hline \multirow[t]{2}{*}{ Author, year } & \multirow{2}{*}{$\begin{array}{l}\text { Number of families, } \\
\text { screened cases both } \\
\text { sporadic and with } \\
\text { family history }\end{array}$} & Individuals screened for $G N A Q$ mutations & \multirow{2}{*}{$\begin{array}{l}\text { Number of } \\
\text { mutations }\end{array}$} & \multirow{2}{*}{$\begin{array}{l}\text { Criteria for } \\
\text { molecular } \\
\text { testing }\end{array}$} \\
\hline & & $\begin{array}{l}\text { Patients with mutation }{ }^{a} / \text { All symptomatic } \\
\text { patients }^{\mathrm{b}}\end{array}$ & & \\
\hline $\begin{array}{l}\text { Shirley et al., } \\
2013 \text { [159] }\end{array}$ & $\begin{array}{c}26 \text { sporadic cases } \\
\text { tested }\end{array}$ & $23 / 26$ & 1 & SWS \\
\hline $\begin{array}{l}\text { Nakashima } \\
\text { et al., } 2014 \\
{[162]}\end{array}$ & $\begin{array}{c}15 \text { sporadic cases } \\
\text { tested }\end{array}$ & $12 / 15$ & 1 & SWS \\
\hline $\begin{array}{l}\text { Uchiyama } \\
\text { et al., } 2016 \\
{[166]}\end{array}$ & $\begin{array}{c}15 \text { sporadic cases } \\
\text { tested }\end{array}$ & $4 / 15$ & 1 & SWS \\
\hline $\begin{array}{l}\text { Huang et al., } \\
2017 \text { [176] }\end{array}$ & One family tested & $3 / 3$ & 1 & SWS \\
\hline $\begin{array}{l}\text { Sundaram } \\
\text { et al., } 2017 \\
{[169]}\end{array}$ & $\begin{array}{l}9 \text { sporadic cases } \\
\text { tested }\end{array}$ & $9 / 9$ & 1 & SWS \\
\hline $\begin{array}{l}\text { Hildebrand } \\
\text { et al., } 2018 \\
{[177]}\end{array}$ & $\begin{array}{c}4 \text { sporadic cases } \\
\text { tested }\end{array}$ & $4 / 4$ & 1 & $\begin{array}{l}\text { Forme } \\
\text { fruste SWS } \\
\text { type III }\end{array}$ \\
\hline
\end{tabular}

${ }^{a}$ Number of individuals subjected to molecular testing. ${ }^{b}$ Individuals with SWS and somatic mutation in GNAQ gene. 'Number of detected mutations (both novel and previously described). SWS - Sturge-Weber syndrome. 
hydrocele [183]. Due to overlapping features, FAH and CLOVES may be considered different phenotypes of a single overgrowth syndrome.

The MCAP phenotype is diversified between affected individuals. The hallmark of the syndrome is an unusual growth dysregulation of the brain and multiple somatic tissues. The typical features in classic MCAP are congenital or early postnatal progressive megalencephaly (MEG) or hemimegalencephaly (HMEG), hypotonia, mild to severe intellectual disability and segmental to generalized somatic overgrowth with single or multifocal capillary malformations. Usually, midline facial capillary malformations - especially persistent naevus flammeus or cutis marmorata - are present. Megalencephaly may be accompanied by secondary overgrowth of the ventricles, corpus callosum and cerebellum followed by cerebellar tonsillar ectopia [188]. The additional findings in MCAP may include cortical malformations such as polymicrogyria, digital abnormalities in the form of polydactyly and syndactyly and connective tissue dysplasia.

The PIK3CA gene (OMIM 171834) is located on chromosome 3 and encodes the catalytic subunit of phosphoinositide-3-kinase ( $\mathrm{PI} 3 \mathrm{~K})$, which is necessary for enzyme activity control. PI3K is involved in phosphorylation of proteins, and takes part in the regeneration of phosphatidylinositol 3,4,5-trisphosphate (PIP3) by multiple phosphorylations of phosphatidylinositol $[191,192]$. Phosphorylation of PDK1 by regenerated PIP3 and then finally phosphorylation of AKT by PDK1 are crucial for activation of the PI3K-AKT-mTOR growth-signaling pathway, which is responsible for cell proliferation, growth and survival (Figure 7) [179, 181, 183, 193, 194].

Kurek et al. found three alterations (c.3140A>G, p.His1047Arg; c.1624G>A, p.Glu542Lys; c.1258T>C, p.Cys420Arg) in PIK3CA in all six tested patients with mutant allele frequencies between $3 \%$ and $30 \%$. Michel et al. reported the aforementioned variants and a newly discovered one (c.3140A $>\mathrm{T}$, p.His 1047Leu) with the prevalence between 1.5\% and $31 \%$ in affected tissues $[180,195]$. The authors suggested that urine may be adequate material for detection of CLOVES causal mutations, which would be a good alternative for biopsy [195]. However, the results of the latest study have revealed that some patients with phenotype characteristic for CLOVES do not show the presence of any known mutations [196]. It may be caused by insufficient accuracy of the proposed experimental method. Alternatively, mutations of PIK3CA do not have to be only cause of the CLOVES phenotype. Regardless of the specific genetic alteration, most academics believe the mutations to be postzygotic and selectively present in the affected body regions $[180,183,188,197]$.

\section{Venous malformations}

Isolated venous malformation is a nonproliferating, slow-flow vascular abnormality that is present at birth. Venous malformations are blue, soft, compressible lesions without excessive warmness of skin covering the malformation [198]. The hallmark of VMs is enlargement of the lesion along with patient's growth. Venous malformation grows from infancy to puberty. It can be located in any region of the body and may extend to neighboring areas. Facial VMs usually affect skin and subcutaneous tissue and often spreads to oral muscles and mucosa [199]. Temporal and cheek lesions may extend to the infratemporal fossa and parotid gland, whereas neck lesions tend to spread posteriorly to the trapezius muscle or anteriorly to the pharyngeal and laryngeal areas [198]. Arteriovenous malformations often present an aesthetic issue but may also lead to serious complications. The lesion of the head can obstruct the airway, be a source of recurrent bleeding and may interfere with speech. Venous malformations on extremities are segmental or localized, but extensive changes have been reported. Extensive VMs may have troublesome complications due to skeletal muscle and joint destruction that leads to either hypotrophy or hypertrophy of the affected extremity [200, 201].

Venous malformations were found to be caused by a somatic gain of function mutation in the TEK gene, which was already mentioned as the causative gene for venous malformations, multiple cutaneous and mucosal syndrome. Known mutations affect the intercellular domain of the TEK protein [143, 202]. Limaye et al. discovered a somatic mutation in 28 of 57 patients diagnosed with sporadic VMs [148]. The characteristic mutation for VMs causes a substitution of leucine with phenylalanine (c.2740C >T, p.Leu914Phe). This sporadic variant has not been observed in patients with VMCMs. The p.Leu914Phe mutation leads to hyperphosphorylation of the TEK protein. It may have an impact on the PI3K/AKT pathway [20]. On the other hand, recent studies indicate that activating mutations of PIK3CA (causative for CLOVES) may be pivotal factors in the context of occurrence of VMs. PIK3CA mutations are mutually exclusive with alterations of the TEK-encoded receptor. These two genes are members of the same signaling pathway [203-205]. Some mosaic somatic mutations of PIK3CA (c.3140A $>\mathrm{G}$, p.His1047Arg; c.1633G>A, p.Glu545Lys) are not related to overgrowth of tissues and abnormalities related to lymphatic vessels, but they may be an explicit factor in the pathogenesis of VMs [205]. In summary, the vast majority of VM cases carry mutations in TEK gene but the alterations of PIK3CA may also be responsible for sporadic cases of VMs [204, 205]. 


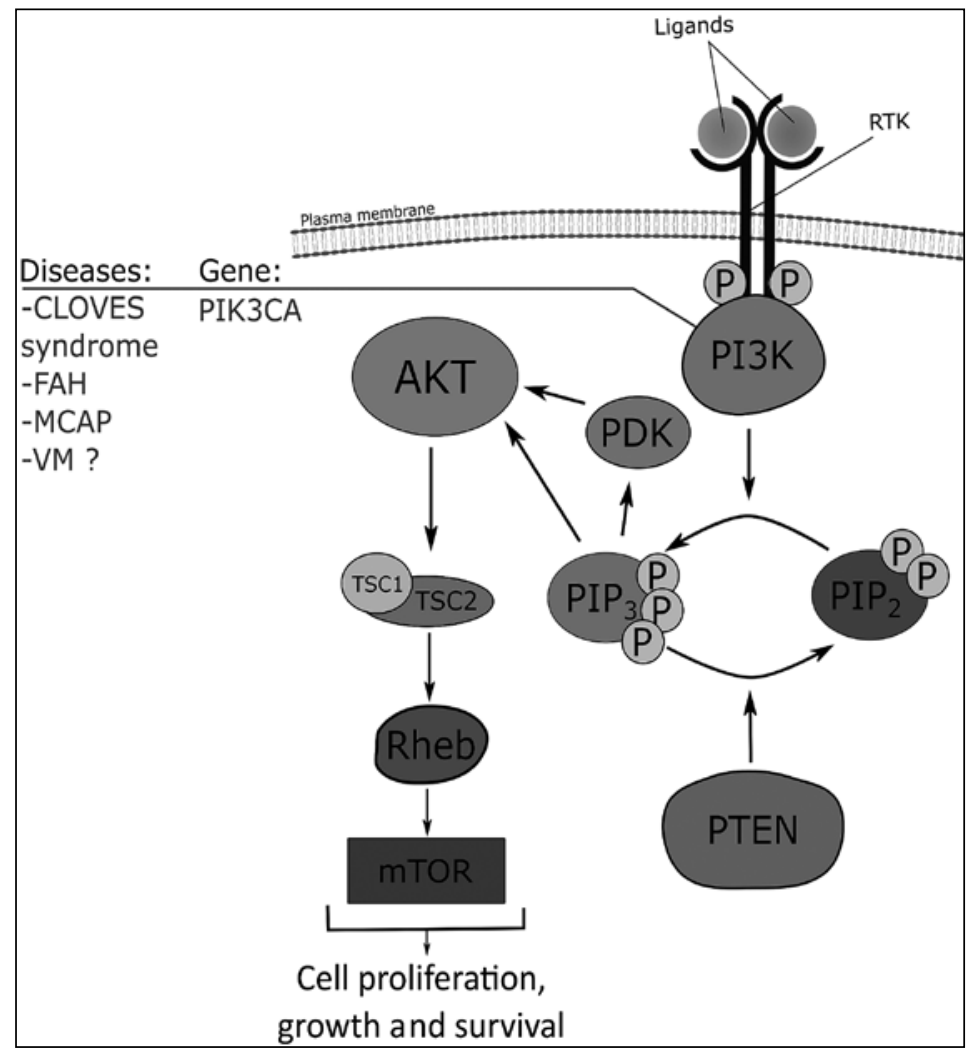

Figure 7. A simplified model of the PI3K-AKT-mTOR growth-signaling pathway. The product of PIK3CA gene expression, the PI3K protein, is essential for the regeneration of phosphatidylinositol 3,4,5-trisphosphate (PIP3), which is required for further phosphorylation steps, first PDK1 by PIP3 and then AKT by PDK1. This triggers further steps of the PI3K-AKT-mTOR cascade important for cell proliferation, growth and survival. Alterations of PIK3CA are responsible for many diseases including those related to vascular system development such as CLOVES syndrome, FAH, MCAP and possibly even VMs [181, 193, 194]

\section{Klippel-Trénaunay-Weber syndrome}

The characteristic feature of Klippel-TrénaunayWeber syndrome (KTWS) is overgrowth of a limb and concurrent large, superficial, cutaneous hemangiomata. The limb overgrowth is associated with both soft tissue and bone hypertrophy. The affected limb bears varicose veins with or without concurrent deep vein abnormalities. Lower limbs are usually affected. The coincidence of upper and lower extremity involvement may occur in $10 \%$ to $15 \%$ of cases and is usually ipsilateral [206]. The VMs affect the entire limb and commonly are present from infancy. The major complications of KTWS are deep venous thrombosis (possibly complicated by life-threatening pulmonary embolism), cellulitis, Kasabach-Merritt syndrome, lymphedema and internal bleeding from abnormal blood vessels. Polydactyly, oligodactyly, syndactyly, macrodactyly and, quite unexpectedly, seizures and intellectual disability have also been reported. The differential diagnosis of the KTWS involves not only CM-AVM syndrome and PWS, but also Servelle-Martorell syndrome associated with capillary macules and varicose veins with relative hypotrophy of the affected extremity [207].
Klippel-Trénaunay-Weber syndrome is estimated to affect 1 in 10,000 newborns. The inheritance pattern of KTWS is unknown, but paradominant inheritance is under consideration. Some authors propose the hypothesis that KTWS may be caused by a mosaic mutation that otherwise would be lethal under non-mosaic conditions [208].

Currently, the exact inheritance of KTWS is unknown. It has been suggested that the disease is sporadic [209-211], but familial cases and a putative autosomal dominant model of inheritance were also considered [212-214]. The researchers have proposed $A G G F 1$, a gene encoding a potent angiogenic factor, as a candidate gene for KTWS [215]. AGGF1 (angiogenic factor with G patch and FHA domains 1, OMIM 608464), also known as $V G 5 Q$, is located on chromosome 5 . The expression product of AGGF1 binds to the surface of endothelial cells and promotes their proliferation [216]; however, recent studies have also shown increased expression of AGGF1 in plump endothelial cells and mast cells [217]. The protein is mainly present on endothelial cells, where it functions as an anti-inflammatory factor, but has also been detected in kidney, heart fibroblasts and ovarian cancer cells [218, 219]. 
Zhang et al. stated that the gene mentioned above is indispensable for angiogenesis as well as tumor growth [220] integrity. [194]. Finally, it has been proposed that genes AGGF1 and PIK3CA may be related due to mutual involvement in the AGGF1PI3K-AKT pathway crucial for vascular system development and also a putative pathogenic factor for [194],[187].KTWS. On the other hand, Barker et al. tested individuals with KTWS for mutations in the AGGF1 gene [221]. Only 1 patient from a group of 24 tested individuals KTWS carried a heterozygous variant in the AGGF1 gene (c.397G>A, p.Glu133Lys). The authors then demonstrated the presence of this variant in 9 individuals out of 275 in the control group [221]. They concluded that the p.Glu133Lys mutation in AGGF1 is probably a nonpathogenic polymorphism of AGGF1 [222].

The second gene suggested to be associated with KTWS was PIK3CA (mentioned above as a cause of CLOVES syndrome and in sporadic cases of VMs) [180]. Firstly, the aspect of overlapping symptoms among patients with KTWS and those with mutations in PIK3CA may suggest a significant connection between this gene and KTWS pathogenesis [223]. Luks et al. used new generation sequencing (NGS) and digital droplet PCR methods for molecular testing of 21 patients with KTWS and lymphatic malformations. Mutations in PIK3CA (previously described in CLOVES - c.3140A>G, p.His1047arg; c.3140A>T, p.His1047Leu;c.1624G>A, p.Glu542Lys; c.1258T>C, p.Cys420Arg) have been found in 13 patients with KTWS (90\%) [196].

Eerola et al. and Wooderchak-Donahue et al. have been investigating patients with prior suspicion of KTWS for the presence of mutations in the RASA1 gene, but all have tested negative $[1,15]$ De Wijn et al. reported on 3 patients with multiple capillary malformations and limb overgrowth, albeit without varicose veins, which most likely represented PWS and 4 patients with atypical CMs and early-onset varicose veins with suspicion of KTWS [14]. In this study a novel heterozygous RASA 1 mutation in exon 3 was identified [14]. In 2013 Revencu et al. tested patients with KTWS and limb overgrowth with and without varicose veins that could mimic PWS on RASA1 mutations. The results did not reveal any pathogenic changes. Thus, Revencu et al. suggested that RASA 1 testing could be a diagnostic method for differentiation between PWS, CM-AVM syndrome and KTWS [208]. Whelan et al. reported on a patient with recognized KTWS with balanced translocation $\mathrm{t}(5 ; 11)$ (q.3; p15.1) that encompasses the locus for RASA 1. This could explain the rare positive results in probands with the KTWS diagnosis [224]. Other genetic abnormalities have been reported as a suspected cause of KTWS, namely translocation $\mathrm{t}(8 ; 14)(\mathrm{q} 22.3 ; \mathrm{q} 13)$, de novo supernumerary ring chromosome 18 and terminal deletion 2q37 [225, 226]. However, none of the above-mentioned changes has been confirmed to be associated with KTWS in further studies.

\section{Summary and results}

In this work, we gathered and summarized available data concerning a selection of ten notable disorders of vascular system development. We presented the clinical picture and molecular background of these relatively rare conditions. The notoriously overlapping symptoms have been listed and assigned to particular syndromes, in the most unambiguous way. Both the familial and sporadic character of selected syndromes as well as their inheritance patterns have been explained. Known mutations and their impact on cellular signaling have been described. Moreover, simplified schemes of pathways involved in vascular system development have been presented and explained. We performed a meta-analysis to determine the frequency of mutations in different cohorts of patients. The results are shown in Tables I-V. Finally the most important data have been placed in the table below (Table VI) for the convenience of both clinicians and geneticists.

In conclusion, the diagnosis of diseases and syndromes related to vascular system development and angiogenesis remains a great concern for both clinicians and genetics. These varied conditions have distinct etiologies, pathomechanisms and prognosis, and thus often require different treatment strategies. Imprecise diagnosis may therefore lead to inadequate therapy. Unfortunately, as demonstrated in this article, those diseases often have overlapping features, making the differential diagnosis difficult or even impossible on clinical grounds alone. So far, both the diagnosis and therapy are based on interventional radiology and surgery. Nevertheless, the whole procedure may encompass genetic testing in addition to thorough clinical and radiological assessment. This multidisciplinary approach, with cooperation between genetics and clinicians, will likely lead to a decrease of mortality and morbidity of affected individuals. That is exemplified by the case of RASA1, which has become a new tool helping in differentiation of patients with PWS, KTWS and CM-AVM syndrome. Further genetic testing should be developed in order to enhance recognition of specific vascular malformation syndromes and to guide therapeutic decisions.

\section{Conflict of interest}

The authors declare no conflict of interest. 


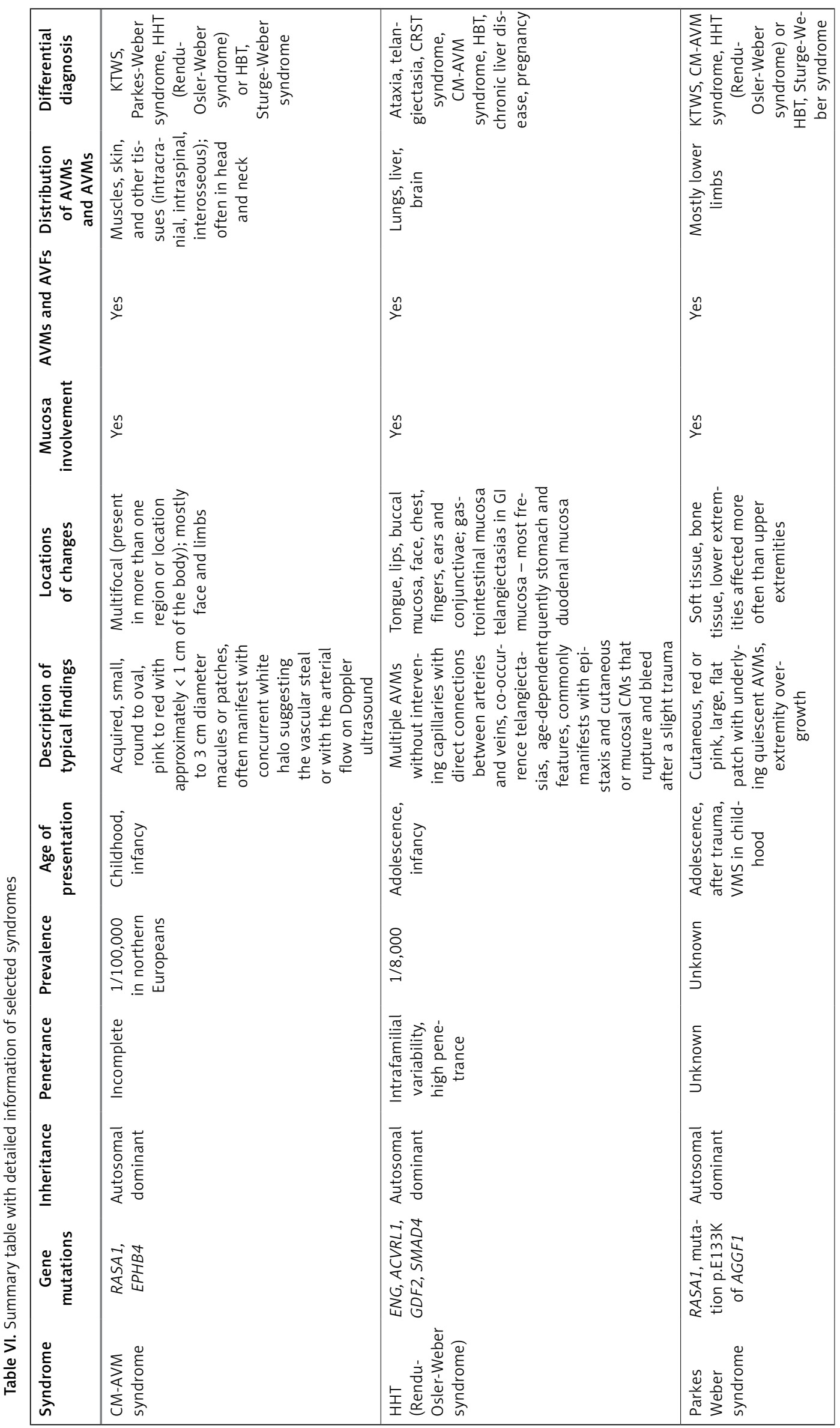


Adam Ustaszewski, Joanna Janowska-Głowacka, Katarzyna Wołyńska, Anna Pietrzak, Magdalena Badura-Stronka

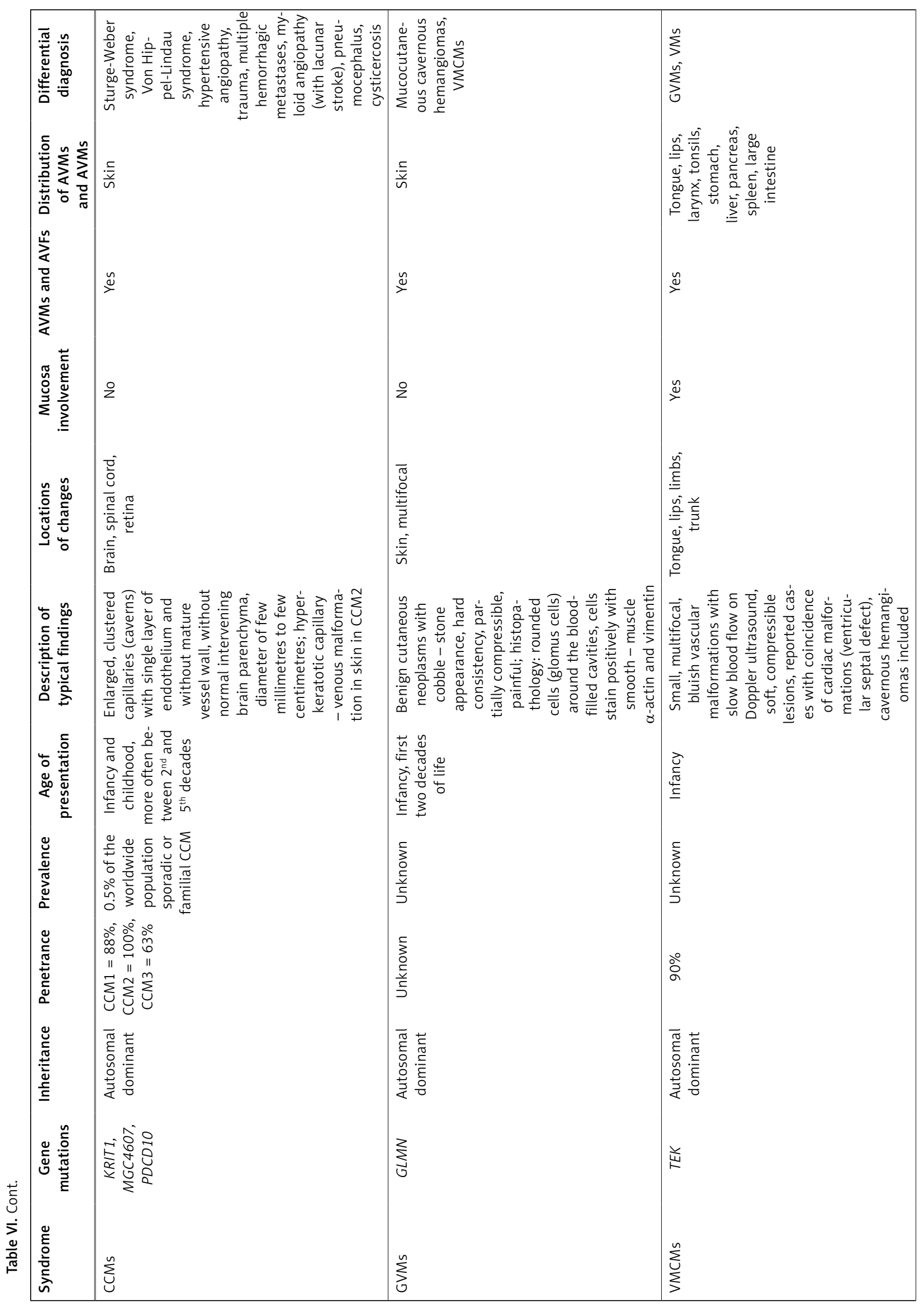




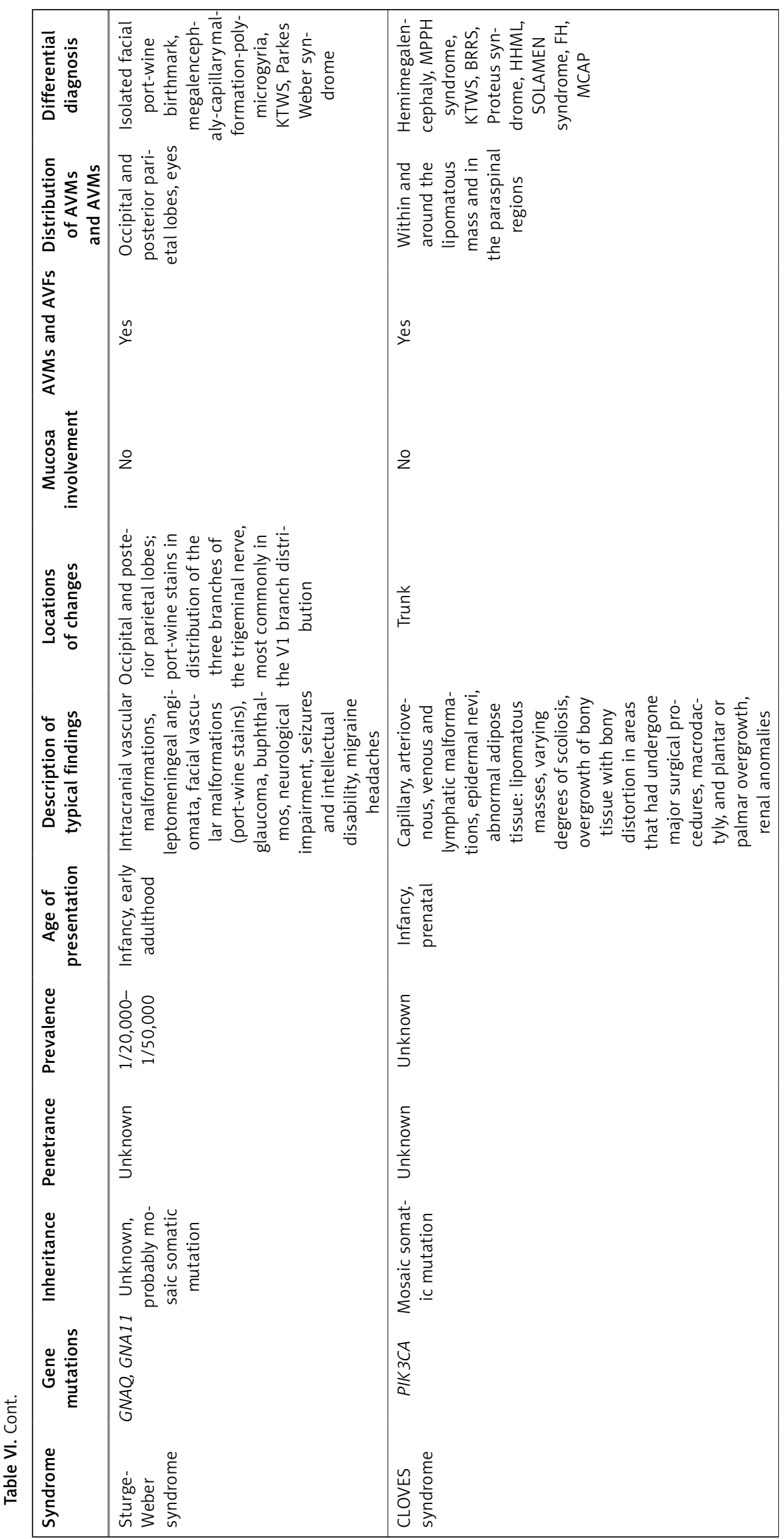


Adam Ustaszewski, Joanna Janowska-Głowacka, Katarzyna Wołyńska, Anna Pietrzak, Magdalena Badura-Stronka

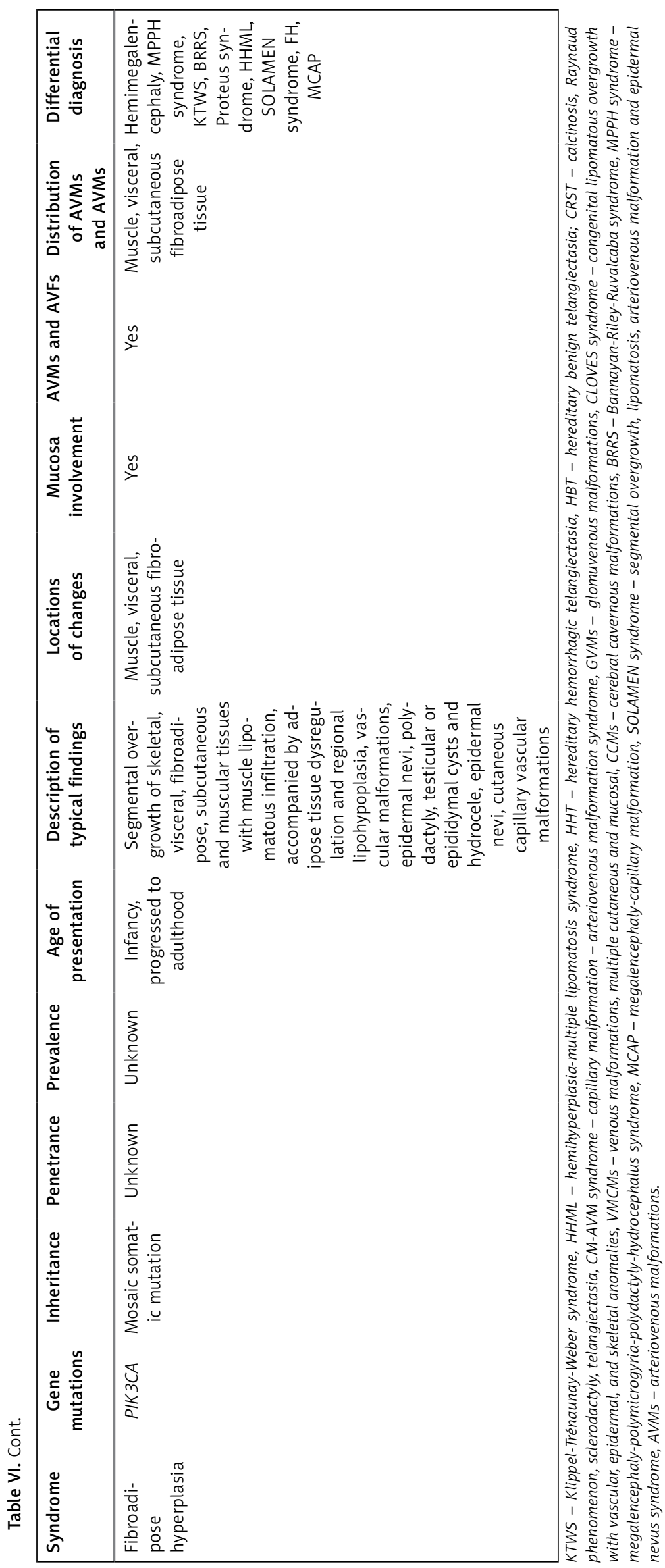




\section{References}

1. Eerola I, Boon LM, Mulliken JB, et al. Capillary malformation-arteriovenous malformation, a new clinical and genetic disorder caused by RASA1 mutations. Am J Hum Genet 2003; 73: 1240-9.

2. Weitz NA, Lauren CT, Behr GG, et al. Clinical spectrum of capillary malformation-arteriovenous malformation syndrome presenting to a pediatric dermatology practice: a retrospective study. Pediatr Dermatol 2015; 32: 76-84.

3. Hershkovitz D, Bercovich D, Sprecher E, Lapidot M. RASA1 mutations may cause hereditary capillary malformations without arteriovenous malformations. $\mathrm{Br}$ J Dermatol 2008; 158: 1035-40.

4. Duffy K. Genetics and syndromes associated with vascular malformations. Pediatr Clin North Am 2010; 57: 1111-20.

5. Chee D, Phillips R, Maixner W, Southwell BR, Hutson JM. The potential of capillary birthmarks as a significant marker for capillary malformation-arteriovenous malformation syndrome in children who had nontraumatic cerebral hemorrhage. J Pediatr Surg 2010; 45: 2419-22.

6. Boon LM, Mulliken JB, Vikkula M. RASA1: variable phenotype with capillary and arteriovenous malformations. Curr Opin Genet Dev 2005; 15: 265-9.

7. Bayrak-Toydemir P, Stevenson D. RASA1-Related Disorders. In: GeneReviews ${ }^{\circledR}$ [Internet]. Adam MP, Ardinger $\mathrm{HH}$, Pagon RA, et al. (eds.). University of Washington, Seattle 1993-2019.

8. Macmurdo CF, Wooderchak-Donahue W, Bayrak-Toydemir P, et al. RASA1 somatic mutation and variable expressivity in capillary malformation/arteriovenous malformation (CM/AVM) syndrome. Am J Med Genet A 2016; 170: 1450-4.

9. Eerola I, Boon LM, Watanabe S, Grynberg H, Mulliken JB, Vikkula M. Locus for susceptibility for familial capillary malformation ("port-wine stain") maps to $5 q$. Eur J Hum Genet 2002; 10: 375-80.

10. Breugem CC, Alders M, Salieb-Beugelaar GB, Mannens MM, Van der Horst CM, Hennekam RC. A locus for hereditary capillary malformations mapped on chromosome 5q. Hum Genet 2002; 110: 343-7.

11. Vikkula M, Boon LM, Mulliken JB. Molecular genetics of vascular malformations. Matrix Biol 2001; 20: 327-35.

12. Garzon MC, Huang JT, Enjolras O, Frieden IJ. Vascular malformations: Part I. J Am Acad Dermatol 2007; 56: 353-70.

13. Thiex R, Mulliken JB, Revencu N, et al. A novel association between RASA1 mutations and spinal arteriovenous anomalies. AJNR Am J Neuroradiol 2010; 31: 775-9.

14. de Wijn RS, Oduber CE, Breugem CC, Alders M, Hennekam RC, van der Horst CM. Phenotypic variability in a family with capillary malformations caused by a mutation in the RASA1 gene. Eur J Med Genet 2012; 55: 191-5.

15. Wooderchak-Donahue W, Stevenson DA, McDonald J, Grimmer JF, Gedge F, Bayrak-Toydemir P. RASA1 analysis: clinical and molecular findings in a series of consecutive cases. Eur J Med Genet 2012; 55: 91-5.

16. Burrows PE, Gonzalez-Garay ML, Rasmussen JC, et al. Lymphatic abnormalities are associated with RASA1 gene mutations in mouse and man. Proc Natl Acad Sci U S A 2013; 110: 8621-6.

17. Yadav P, De Castro DK, Waner M, Meyer L, Fay A. Vascular anomalies of the head and neck: a review of genetics. Semin Ophthalmol 2013; 28: 257-66.
18. Català A, Roé E, Vikkula M, Baselga E. Capillary malformation-arteriovenous malformation syndrome: a report of 2 cases, diagnostic criteria, and management. Actas Dermosifiliogr 2013; 104: 710-3

19. Larralde M, Abad ME, Luna PC, Hoffner MV. Capillary malformation-arteriovenous malformation: a clinical review of 45 patients. Int I Dermatol 2014; 53: 458-61.

20. Nguyen HL, Boon LM, Vikkula M. Genetics of vascular malformations. Semin Pediatr Surg 2014; 23: 221-6.

21. Kim C, Ko CJ, Baker KE, Antaya RJ. Histopathologic and ultrasound characteristics of cutaneous capillary malformations in a patient with capillary malformation-arteriovenous malformation syndrome. Pediatr Dermatol 2015; 32: 128-31.

22. Grillner P, Soderman M, Holmin S, Rodesch G. A spectrum of intracranial vascular high-flow arteriovenous shunts in RASA1 mutations. Childs Nerv Syst 2016; 32: 709-15.

23. Chugh AJ, Shahid A, Manjila S, Gulati D, Bambakidis NC. Pial arteriovenous fistula and capillary malformation-arteriovenous malformation associated with RASA1 mutation: 2 pediatric cases with successful surgical management. Pediatr Neurosurg 2017; 52: 261-7.

24. Duran D, Karschnia P, Gaillard JR, et al. Human genetics and molecular mechanisms of vein of Galen malformation. J Neurosurg Pediatr 2018; 21: 367-74.

25. Hernandez F, Huether R, Carter L, et al. Mutations in RASA1 and GDF2 identified in patients with clinical features of hereditary hemorrhagic telangiectasia. Hum Genome Var 2015; 2: 15040.

26. Revencu N, Boon LM, Mulliken JB, et al. Parkes Weber syndrome, vein of Galen aneurysmal malformation, and other fast-flow vascular anomalies are caused by RASA1 mutations. Hum Mutat 2008; 29: 959-65.

27. McCormick F. ras GTPase activating protein: signal transmitter and signal terminator. Cell 1989; 56: 5-8.

28. Pamonsinlapatham P, Hadj-Slimane R, Lepelletier $Y$, et al. p120-Ras GTPase activating protein (RasGAP): a multi-interacting protein in downstream signaling. Biochimie 2009; 91: 320-8.

29. Henkemeyer M, Rossi DJ, Holmyard DP, et al. Vascular system defects and neuronal apoptosis in mice lacking ras GTPase-activating protein. Nature 1995; 377: 695-701.

30. Kulkarni SV, Gish G, van der Geer P, Henkemeyer M, Pawson T. Role of p120 Ras-GAP in directed cell movement. J Cell Biol 2000; 149: 457-70.

31. Frigerio A, Stevenson DA, Grimmer JF. The genetics of vascular anomalies. Curr Opin Otolaryngol Head Neck Surg 2012; 20: 527-32.

32. Carr CW, Zimmerman HH, Martin CL, Vikkula M, Byrd AC, Abdul-Rahman OA. 5q14.3 neurocutaneous syndrome: a novel continguous gene syndrome caused by simultaneous deletion of RASA1 and MEF2C. Am J Med Genet A 2011; 155A: 1640-5.

33. Malumbres $M$, Barbacid M. RAS oncogenes: the first 30 years. Nat Rev Cancer 2003; 3: 459-65.

34. Malumbres M, Pellicer A. RAS pathways to cell cycle control and cell transformation. Front Biosci 1998; 3: d887-912.

35. de Castro Carpeño J, Belda-Iniesta C. KRAS mutant NSCLC, a new opportunity for the synthetic lethality therapeutic approach. Transl Lung Cancer Res 2013; 2: 142-51.

36. Castellano E, Downward J. Role of RAS in the regulation of PI 3-kinase. Curr Top Microbiol Immunol 2010; 346: $143-69$. 
37. Cox AD, Der CJ. The dark side of Ras: regulation of apoptosis. Oncogene 2003; 22: 8999-9006.

38. Dienstmann R, Rodon J, Serra V, Tabernero J. Picking the point of inhibition: a comparative review of PI3K/ AKT/mTOR pathway inhibitors. Mol Cancer Ther 2014; 13: 1021-31.

39. Yu J, Streicher JL, Medne L, Krantz ID, Yan AC. EPHB4 Mutation implicated in capillary malformation-arteriovenous malformation syndrome: a case report. Pediatr Dermatol 2017; 34: e227-e230.

40. Amyere M, Revencu N, Helaers R, et al. Germline lossof-function mutations in EPHB4 cause a second form of capillary malformation-arteriovenous malformation (CM-AVM2) deregulating RAS-MAPK signaling. Circulation 2017; 136: 1037-48.

41. Kim I, Ryu YS, Kwak HJ, et al. EphB ligand, ephrinB2, suppresses the VEGF- and angiopoietin 1-induced Ras/ mitogen-activated protein kinase pathway in venous endothelial cells. FASEB J 2002; 16: 1126-8.

42. Hershkovitz D, Bergman R, Sprecher E. A novel mutation in RASA1 causes capillary malformation and limb enlargement. Arch Dermatol Res 2008; 300: 385-8.

43. Durrington HJ, Firth HV, Patient C, et al. A novel RASA1 mutation causing capillary malformation-arteriovenous malformation (CM-AVM) presenting during pregnancy. Am J Med Genet A 2013; 161A: 1690-4.

44. Revencu N, Boon LM, Mendola A, et al. RASA1 mutations and associated phenotypes in 68 families with capillary malformation-arteriovenous malformation. Hum Mutat 2013; 34: 1632-41.

45. Whitaker S, Leech S, Taylor A, Splitt M, Natarajan S, Rajan N. Multifocal capillary malformations in an older, asymptomatic child with a novel RASA1 mutation. Clin Exp Dermatol 2016; 41: 156-8.

46. Olitsky SE. Hereditary hemorrhagic telangiectasia: diagnosis and management. Am Fam Physician 2010; 82: 785-90.

47. McDonald J, Pyeritz RE: Hereditary hemorrhagic telangiectasia. In: GeneReviews ${ }^{\oplus}$ [Internet]. Adam MP, Ardinger HH, Pagon RA, et al. (eds.). University of Washington, Seattle 1993-2019.

48. Berg J, Porteous M, Reinhardt D, et al. Hereditary haemorrhagic telangiectasia: a questionnaire based study to delineate the different phenotypes caused by endoglin and ALK1 mutations. J Med Genet 2003; 40: 585-90.

49. Kjeldsen AD, Kjeldsen J. Gastrointestinal bleeding in patients with hereditary hemorrhagic telangiectasia. Am J Gastroenterol 2000; 95: 415-8.

50. Plauchu H, de Chadarevian JP, Bideau A, Robert JM. Age-related clinical profile of hereditary hemorrhagic telangiectasia in an epidemiologically recruited population. Am J Med Genet 1989; 32: 291-7.

51. McDonald J, Bayrak-Toydemir P, Pyeritz RE. Hereditary hemorrhagic telangiectasia: an overview of diagnosis, management, and pathogenesis. Genet Med 2011; 13: 607-16.

52. Ianora AA, Memeo M, Sabba C, Cirulli A, Rotondo A, Angelelli G. Hereditary hemorrhagic telangiectasia: multi-detector row helical CT assessment of hepatic involvement. Radiology 2004; 230: 250-9.

53. Argyriou L, Twelkemeyer S, Panchulidze I, et al. Novel mutations in the ENG and ACVRL1 genes causing hereditary hemorrhagic teleangiectasia. Int I Mol Med 2006; 17: 655-9.

54. Ruiz-Llorente L, Gallardo-Vara E, Rossi E, Smadja DM, Botella LM, Bernabeu C. Endoglin and alk1 as thera- peutic targets for hereditary hemorrhagic telangiectasia. Expert Opin Ther Targets 2017; 21: 933-947.

55. Li W, Salmon RM, Jiang H, Morrell NW. Regulation of the ALK1 ligands, BMP9 and BMP10. Biochem Soc Trans 2016; 44: 1135-41.

56. Gkatzis K, Thalgott J, Dos-Santos-Luis D, et al. Interaction between ALK1 signaling and connexin40 in the development of arteriovenous malformations. Arterioscler Thromb Vasc Biol 2016; 36: 707-17.

57. Peacock HM, Caolo V, Jones EA. Arteriovenous malformations in hereditary haemorrhagic telangiectasia: looking beyond ALK1-NOTCH interactions. CardiovasC Res 2016; 109: 196-203.

58. Buscarini E, Leandro G, Conte D, et al. Natural history and outcome of hepatic vascular malformations in a large cohort of patients with hereditary hemorrhagic teleangiectasia. Dig Dis Sci 2011; 56: 2166-78.

59. Jonker L. TGF- $\beta$ \& BMP receptors endoglin and ALK1: overview of their functional role and status as antiangiogenic targets. Microcirculation 2014; 21: 93-103.

60. McDonald J, Wooderchak-Donahue W, VanSant Webb C, Whitehead K, Stevenson DA, Bayrak-Toydemir P. Hereditary hemorrhagic telangiectasia: genetics and molecular diagnostics in a new era. Front Genet 2015; 6: 1 .

61. Abdalla SA, Letarte M. Hereditary haemorrhagic telangiectasia: current views on genetics and mechanisms of disease. J Med Genet 2006; 43: 97-110.

62. Tørring PM, Kjeldsen AD, Ousager LB, Brusgaard K. ENG mutational mosaicism in a family with hereditary hemorrhagic telangiectasia. Mol Genet Genomic Med 2018; 6: 121-5.

63. Lebrin F, Deckers M, Bertolino P, Ten Dijke P. TGF-beta receptor function in the endothelium. Cardiovasc Res 2005; 65: 599-608.

64. Rossi E, Lopez-Novoa JM, Bernabeu C. Endoglin involvement in integrin-mediated cell adhesion as a putative pathogenic mechanism in hereditary hemorrhagic telangiectasia type 1 (HHT1). Front Genet 2015; 5: 457.

65. Lin S, Xie J, Gong T, et al. Smad signal pathway regulates angiogenesis via endothelial cell in an adipose-derived stromal cell/endothelial cell co-culture, 3D gel model. Mol Cell Biochem 2016; 412: 281-8.

66. Yan X, Liu Z, Chen Y. Regulation of TGF-beta signaling by Smad7. Acta Biochim Biophys Sin (Shanghai) 2009; 41: 263-72.

67. Miao ZF, Wu JH, Wang ZN, et al. Endoglin overexpression mediates gastric cancer peritoneal dissemination by inducing mesothelial cell senescence. Hum Pathol 2016; 51: 114-23.

68. Torsney E, Charlton R, Parums D, Collis M, Arthur HM Inducible expression of human endoglin during inflammation and wound healing in vivo. Inflamm Res 2002; 51: 464-70.

69. Saito T, Bokhove M, Croci R, et al. Structural basis of the human endoglin-BMP9 interaction: insights into BMP signaling and HHT1. Cell Rep 2017; 19: 1917-28.

70. Giordano P, Nigro A, Lenato GM, et al. Screening for children from families with Rendu-Osler-Weber disease: from geneticist to clinician. J Thromb Haemost 2006; 4: 1237-45.

71. Hume AN, John A, Akawi NA, et al. Retention in the endoplasmic reticulum is the underlying mechanism of some hereditary haemorrhagic telangiectasia type 2 ALK1 missense mutations. Mol Cell Biochem 2013; 373: 247-57.

72. Blanco FJ, Santibanez JF, Guerrero-Esteo M, Langa C, Vary CP, Bernabeu C. Interaction and functional inter- 
play between endoglin and ALK-1, two components of the endothelial transforming growth factor-beta receptor complex. J Cell Physiol 2005; 204: 574-84.

73. Pan CC, Kumar S, Shah N, et al. Src-mediated posttranslational regulation of endoglin stability and function is critical for angiogenesis. J Biol Chem 2014; 289: 25486-96.

74. Wooderchak-Donahue WL, McDonald J, O'Fallon B, et al. BMP9 mutations cause a vascular-anomaly syndrome with phenotypic overlap with hereditary hemorrhagic telangiectasia. Am J Hum Genet. 2013; 93: 530-7.

75. Varadaraj A, Patel P, Serrao A, et al. Epigenetic regulation of GDF2 suppresses anoikis in ovarian and breast epithelia. Neoplasia 2015; 17: 826-38.

76. Herrera B, Garcia-Alvaro M, Cruz S, et al. BMP9 is a proliferative and survival factor for human hepatocellular carcinoma cells. PLoS One 2013; 8: e69535.

77. Vorselaars VMM, Diederik A, Prabhudesai V, et al. SMAD4 gene mutation increases the risk of aortic dilation in patients with hereditary haemorrhagic telangiectasia. Int J Cardiol 2017; 245: 114-8.

78. Heald B, Rigelsky C, Moran R, et al. Prevalence of thoracic aortopathy in patients with juvenile polyposis syndrome-hereditary hemorrhagic telangiectasia due to SMAD4. Am J Med Genet A 2015; 167A: 1758-62.

79. Cavalli G. SMAD4 gene mutation and risk of aortic dilation: Lessons from hereditary hemorrhagic telangiectasia. Int J Cardiol 2017; 245: 145-6.

80. Lesca G, Plauchu H, Coulet F, et al. Molecular screening of ALK1/ACVRL1 and ENG genes in hereditary hemorrhagic telangiectasia in France. Hum Mutat 2004; 23: 289-99.

81. Schulte C, Geisthoff U, Lux A, et al. High frequency of ENG and ALK1/ACVRL1 mutations in German HHT patients. Hum Mutat 2005; 25: 595.

82. Bossler AD, Richards J, George C, Godmilow L, Ganguly A. Novel mutations in ENG and ACVRL1 identified in a series of 200 individuals undergoing clinical genetic testing for hereditary hemorrhagic telangiectasia (HHT): correlation of genotype with phenotype. Hum Mutat 2006; 27: 667-75.

83. Olivieri C, Pagella F, Semino L, et al. Analysis of ENG and ACVRL1 genes in $137 \mathrm{HHT}$ Italian families identifies 76 different mutations (24 novel). Comparison with other European studies. J Hum Genet 2007; 52: 820-9.

84. Plumitallo S, Ruiz-Llorente L, Langa C, et al. Functional analysis of a novel ENG variant in a patient with hereditary hemorrhagic telangiectasia (HHT) identifies a new Sp1 binding-site. Gene 2018; 647: 85-92.

85. Banzic I, Brankovic M, Maksimović Ž, Davidović L, Marković M, Rančić Z. Parkes Weber syndrome - diagnostic and management paradigms: A systematic review. Phlebology 2017; 32: 371-83.

86. Ninagawa J, Yamada Y. General anesthesia in a patient with Parkes Weber syndrome with high-output cardiac failure due to multiple arteriovenous fistulas complicated by severe aortic regurgitation. J Anesth 2010; 24: 256-9.

87. Li ZF, Li Q, Xu Y, Hong B, Huang QH, Liu JM. Spinal arteriovenous malformation associated with Parkes Weber syndrome: report of two cases and literature review. World Neurosurg 2017; 107: 1043.e7-e13.

88. Manresa-Manresa F, Iribarren-Marin MA, Gomez-Ruiz FT. Parkes-Weber syndrome. Rev Esp Cardiol (Engl Ed) 2015; 68: 67.

89. Wetzel-Strong SE, Detter MR, Marchuk DA. The pathobiology of vascular malformations: insights from hu- man and model organism genetics. J Pathol 2017; 241: 281-93.

90. Choudhri O, Feroze AH, Lad EM, et al. Co-occurrence of a cerebral cavernous malformation and an orbital cavernous hemangioma in a patient with seizures and visual symptoms: Rare crossroads for vascular malformations. Surg Neurol Int 2014; 5 (Suppl 4): S148-54.

91. Dziedzic T, Kunert P, Matyja E, Ziora-Jakutowicz K, Sidoti A, Marchel A. Familial cerebral cavernous malformation. Folia Neuropathol 2012; 50: 152-8.

92. Morrison L, Akers A. Cerebral cavernous malformation, familial. In: GeneReviews ${ }^{\oplus}$ [Internet]. Adam MP, Ardinger HH, Pagon RA, et al. (eds.). University of Washington, Seattle 1993-2019.

93. Denier C, Labauge P, Brunereau L, et al. Clinical features of cerebral cavernous malformations patients with KRIT1 mutations. Ann Neurol 2004; 55: 213-20.

94. Choquet H, Nelson J, Pawlikowska L, et al. Association of cardiovascular risk factors with disease severity in cerebral cavernous malformation type 1 subjects with the common Hispanic mutation. Cerebrovasc Dis 2014; 37: 57-63.

95. Liquori CL, Berg MJ, Siegel AM, et al. Mutations in a gene encoding a novel protein containing a phosphotyrosine-binding domain cause type 2 cerebral cavernous malformations. Am J Hum Genet 2003; 73: 1459-64.

96. Stamatovic SM, Sladojevic N, Keep RF, Andjelkovic AV. PDCD10 (CCM3) regulates brain endothelial barrier integrity in cerebral cavernous malformation type 3 : role of CCM3-ERK1/2-cortactin cross-talk. Acta Neuropathol 2015; 130: 731-50.

97. Fischer A, Zalvide J, Faurobert E, Albiges-Rizo C, TournierLasserve E. Cerebral cavernous malformations: from CCM genes to endothelial cell homeostasis. Trends $\mathrm{Mol}$ Med 2013; 19: 302-8.

98. Storkebaum E, Quaegebeur A, Vikkula M, Carmeliet P. Cerebrovascular disorders: molecular insights and therapeutic opportunities. Nat Neurosci 2011; 14: 1390-7.

99. Draheim KM, Fisher OS, Boggon TJ, Calderwood DA. Cerebral cavernous malformation proteins at a glance. J Cell Sci 2014; 127: 701-7.

100. Baranoski JF, Kalani MY, Przybylowski CJ, Zabramski JM. Cerebral cavernous malformations: review of the genetic and protein-protein interactions resulting in disease pathogenesis. Front Surg 2016; 3: 60.

101. Stockton RA, Shenkar R, Awad IA, Ginsberg MH. Cerebral cavernous malformations proteins inhibit Rho kinase to stabilize vascular integrity. J Exp Med 2010; 207: 881-96.

102. Yao L, Romero MJ, Toque HA, Yang G, Caldwell RB, Caldwell RW. The role of RhoA/Rho kinase pathway in endothelial dysfunction. J Cardiovasc Dis Res 2010; 1: 165-70.

103. Denniss SG, Jeffery AJ, Rush JW. RhoA-Rho kinase signaling mediates endothelium- and endoperoxide-dependent contractile activities characteristic of hypertensive vascular dysfunction. Am J Physiol Heart Circ Physiol 2010; 298: H1391-405.

104. Glading A, Han J, Stockton RA, Ginsberg MH. KRIT-1/ CCM1 is a Rap1 effector that regulates endothelial cell cell junctions. J Cell Biol 2007; 179: 247-54.

105. Zawistowski JS, Stalheim L, Uhlik MT, et al. CCM1 and CCM2 protein interactions in cell signaling: implications for cerebral cavernous malformations pathogenesis. Hum Mol Genet 2005; 14: 2521-31.

106. Voss K, Stahl S, Schleider E, et al. CCM3 interacts with CCM2 indicating common pathogenesis for cerebral 
cavernous malformations. Neurogenetics 2007; 8: 249-56.

107. Chen L, Tanriover G, Yano H, Friedlander R, Louvi A Gunel M. Apoptotic functions of PDCD10/CCM3, the gene mutated in cerebral cavernous malformation 3 . Stroke 2009; 40: 1474-81.

108. Zhu Y, Wu Q, Xu JF, et al. Differential angiogenesis function of CCM2 and CCM3 in cerebral cavernous malformations. Neurosurg Focus 2010; 29: E1.

109. Richardson BT, Dibble CF, Borikova AL, Johnson GL. Cerebral cavernous malformation is a vascular disease associated with activated RhoA signaling. Biol Chem 2013; 394: 35-42.

110. Louvi A, Nishimura S, Gunel M. Ccm3, a gene associated with cerebral cavernous malformations, is required for neuronal migration. Development 2014; 141: 1404-15.

111. Scimone C, Bramanti P, Alafaci C, et al. Update on nove CCM gene mutations in patients with cerebral cavernous malformations. J Mol Neurosci 2017; 61: 189-98.

112. Spiegler S, Najm J, Liu J, et al. High mutation detection rates in cerebral cavernous malformation upon stringent inclusion criteria: one-third of probands are minors. Mol Genet Genomic Med 2014; 2: 176-85.

113. Liquori CL, Penco S, Gault J, et al. Different spectra of genomic deletions within the CCM genes between Italian and American CCM patient cohorts. Neurogenetics 2008; 9: 25-31.

114. Spiegler S, Rath M, Hoffjan S, et al. First large genomic inversion in familial cerebral cavernous malformation identified by whole genome sequencing. Neurogenetics 2018; 19: 55-9.

115. Tang AT, Choi JP, Kotzin JJ, et al. Endothelial TLR4 and the microbiome drive cerebral cavernous malformations. Nature 2017; 545: 305-10.

116. Stahl S, Gaetzner S, Voss K, et al. Novel CCM1, CCM2, and CCM3 mutations in patients with cerebral cavernous malformations: in-frame deletion in $\mathrm{CCM} 2$ prevents formation of a CCM1/CCM2/CCM3 protein complex. Hum Mutat 2008; 29: 709-17.

117. Cigoli MS, Avemaria F, De Benedetti S, et al. PDCD10 gene mutations in multiple cerebral cavernous malformations. PLoS One 2014; 9: e110438.

118. Mondéjar R, Solano F, Rubio R, et al. Mutation prevalence of cerebral cavernous malformation genes in Spanish patients. PLoS One 2014; 9: e86286.

119. Cigoli MS, De Benedetti S, Marocchi A, et al. A novel MGC4607/CCM2 gene mutation associated with cerebral spinal and cutaneous cavernous angiomas. J Mol Neurosci 2015; 56: 602-7.

120. Hirota K, Akagawa H, Kikuchi A, et al. KRIT1 mutations in three Japanese pedigrees with hereditary cavernous malformation. Hum Genome Var 2016; 3: 16032.

121. Yang C, Zhao J, Wu B, Zhong H, Li Y, Xu Y. Identification of a novel deletion mutation (c.1780delG) and a Novel Splice-Site Mutation (c.1412-1G>A) in the CCM1/ KRIT1 gene associated with familial cerebral cavernous malformation in the Chinese Population. J Mol Neurosci 2017; 61: 8-15.

122. Brouillard P, Boon LM, Mulliken JB, et al. Mutations in a novel factor, glomulin, are responsible for glomuvenous malformations ("glomangiomas"). Am J Hum Genet 2002; 70: 866-74.

123. Jha A, Khunger N, Malarvizhi K, Ramesh V, Singh A. Familial disseminated cutaneous glomuvenous malformation: treatment with polidocanol sclerotherapy. J Cutan Aesthet Surg 2016; 9: 266-9.
124. Amyere M, Aerts V, Brouillard P, et al. Somatic uniparental isodisomy explains multifocality of glomuvenous malformations. Am J Hum Genet 2013; 92: 188-96.

125. Duda DM, Olszewski J, Tron AE, et al. Structure of a glomulin-RBX1-CUL1 complex: inhibition of a RING E3 ligase through masking of its E2-binding surface. Mol Cell 2012; 47: 371-82

126. Tron AE, Arai T, Duda DM, et al. The glomuvenous malformation protein Glomulin binds Rbx1 and regulates cullin RING ligase-mediated turnover of Fbw7. Mol Cell 2012; 46: 67-78

127. Huang DT, Ayrault O, Hunt HW, et al. E2-RING expansion of the NEDD8 cascade confers specificity to cullin modification. Mol Cell 2009; 33: 483-95.

128. Kamura T, Maenaka K, Kotoshiba S, et al. VHL-box and SOCS-box domains determine binding specificity for Cul2-Rbx1 and Cul5-Rbx2 modules of ubiquitin ligases. Genes Dev 2004; 18: 3055-65.

129. Spratt DE, Wu K, Kovacev J, Pan ZQ, Shaw GS. Selective recruitment of an E2 ubiquitin complex by an E3 ubiquitin ligase. J Biol Chem 2012; 287: 17374-85.

130. McIntyre BA, Brouillard P, Aerts V, Gutierrez-Roelens I, Vikkula M. Glomulin is predominantly expressed in vascular smooth muscle cells in the embryonic and adult mouse. Gene Expr Patterns 2004; 4: 351-8.

131. Smit JJ, Sixma TK. RBR E3-ligases at work. EMBO Rep 2014; 15: 142-54.

132. Magori S, Citovsky V. Hijacking of the host SCF ubiquitin ligase machinery by plant pathogens. Front Plant Sci $2011 ; 2: 87$.

133. Hristova VA, Stringer DK, Weissman AM. Cullin RING ligases: glommed by glomulin. Mol Cell 2012; 47: 331-2.

134. Iqbal A, Cormack GC, Scerri G. Hereditary multiple glomangiomas. Br J Plast Surg 1998; 51: 32-7.

135. Rudolph R. Familial multiple glomangiomas. Ann Plast Surg 1993; 30: 183-5.

136. Boon LM, Mulliken JB, Enjolras O, Vikkula M. Glomuvenous malformation (glomangioma) and venous malformation: distinct clinicopathologic and genetic entities. Arch Dermatol 2004; 140: 971-6.

137. Chen AY, Eide M, Shwayder T. Glomuvenous malformation in a boy with transposition of the great vessels: a case report and review of literature. Pediatr Dermato 2009; 26: 70-4

138. Brouillard P, Boon LM, Revencu N, et al. Genotypes and phenotypes of 162 families with a glomulin mutation. Mol Syndromol 2013; 4: 157-64

139. Ohata C, Matsuda M, Hamada T, et al. Loss of het erozygosity in a case of glomuvenous malformations. J Dermatol 2015; 42: 646-7.

140. Brouillard P, Ghassibe M, Penington A, et al. Four common glomulin mutations cause two thirds of glomuvenous malformations ("familial glomangiomas"): evi dence for a founder effect. J Med Genet 2005; 42: e13.

141. O'Hagan AH, Moloney FJ, Buckley C, et al. Mutation analysis in Irish families with glomuvenous malformations. Br J Dermatol 2006; 154: 450-2.

142. Pasyk KA, Argenta LC, Erickson RP. Familial vascular malformations. Report of 25 members of one family. Clin Genet 1984; 26: 221-7.

143. Wouters V, Limaye N, Uebelhoer M, et al. Hereditary cutaneomucosal venous malformations are caused by TIE2 mutations with widely variable hyper-phosphorylating effects. Eur J Hum Genet 2010; 18: 414-20.

144. Shu W, Lin Y, Hua R, et al. Cutaneomucosal venous malformations are linked to the TIE2 mutation in a large Chinese family. Exp Dermatol 2012; 21: 456-7. 
145. Khan AA, Sandhya VK, Singh P, Parthasarathy D, Ku mar A, Advani J. Signaling network map of endothelial TEK tyrosine kinase. J Signal Transduct 2014; 2014: 173026.

146. Fukuhara S, Sako K, Minami T, et al. Differential function of Tie 2 at cell-cell contacts and cell-substratum contacts regulated by angiopoietin-1. Nat Cell Biol 2008; 10: 513-26.

147. Lee MY, Luciano AK, Ackah E, et al. Endothelial Akt1 mediates angiogenesis by phosphorylating multiple angiogenic substrates. Proc Natl Acad Sci U S A 2014 111: $12865-70$.

148. Limaye N, Wouters V, Uebelhoer M, et al. Somatic mu tations in angiopoietin receptor gene TEK cause solitary and multiple sporadic venous malformations. Nat Genet 2009; 41: 118-24.

149. Jones N, Iljin K, Dumont DJ, Alitalo K. Tie receptors: new modulators of angiogenic and lymphangiogenic responses. Nat Rev Mol Cell Biol 2001; 2: 257-67.

150. Dumont DJ, Yamaguchi TP, Conlon RA, Rossant J, Breitman ML. TEK, a novel tyrosine kinase gene located on mouse chromosome 4 , is expressed in endothelial cells and their presumptive precursors. Oncogene 1992; 7: 1471-80.

151. Huang H, Bhat A, Woodnutt G, Lappe R. Targeting the ANGPT-TIE2 pathway in malignancy. Nat Rev Cancer 2010; 10: 575-85.

152. Boon LM, Vikkula M. Multiple cutaneous and mucosa venous malformations. In: GeneReviews ${ }^{\circledast}$ [Internet]. Adam MP, Ardinger HH, Pagon RA, et al. (eds.). University of Washington, Seattle 1993-2019.

153. Korpelainen El, Kärkkäinen M, Gunji Y, Vikkula M, Alitalo K. Endothelial receptor tyrosine kinases activate the STAT signaling pathway: mutant Tie-2 causing venous malformations signals a distinct STAT activation response. Oncogene 1999; 18: 1-8.

154. Thomas-Sohl KA, Vaslow DF, Maria BL. Sturge-Weber syndrome: a review. Pediatr Neurol 2004; 30: 303-10.

155. Nabbout R, Juhasz C. Sturge-Weber syndrome. Handb Clin Neurol 2013; 111: 315-21.

156. Tallman B, Tan OT, Morelli JG, et al. Location of portwine stains and the likelihood of ophthalmic and/ or central nervous system complications. Pediatrics 1991; 87: 323-7.

157. Comi AM. Presentation, diagnosis, pathophysiology, and treatment of the neurological features of Sturge-Weber syndrome. Neurologist 2011; 17: 179-84.

158. Huq AH, Chugani DC, Hukku B, Serajee FJ. Evidence of somatic mosaicism in Sturge-Weber syndrome. Neurology 2002; 59: 780-2.

159. Shirley MD, Tang H, Gallione CJ, et al. Sturge-Weber syndrome and port-wine stains caused by somatic mutation in GNAQ. N Engl J Med 2013; 368: 1971-9.

160. Martins L, Giovani PA, Reboucas PD, et al. Computational analysis for GNAQ mutations: New insights on the molecular etiology of Sturge-Weber syndrome. J Mol Graph Model 2017; 76: 429-40.

161. Lian CG, Sholl LM, Zakka LR, et al. Novel genetic mutations in a sporadic port-wine stain. JAMA Dermatol 2014; 150: 1336-40.

162. Nakashima M, Miyajima $M$, Sugano $H$, et al. The so matic GNAQ mutation c.548G >A (p.R183Q) is consistently found in Sturge-Weber syndrome. J Hum Genet 2014; 59: 691-3.

163. Pinto A, Sahin M, Pearl PL. Epileptogenesis in neuro cutaneous disorders with focus in Sturge Weber syndrome. F1000Res 2016; 5. pii: F1000 Faculty Rev-370.
164. Litosch I. Regulation of phospholipase C-beta(1) GTPase-activating protein (GAP) function and relationship to G(q) efficacy. IUBMB Life 2013; 65: 936-40.

165. Riddy DM, Delerive P, Summers RJ, Sexton PM, Langmead CJ. G Protein-coupled receptors targeting insulin resistance, obesity, and type 2 diabetes mellitus. Pharmacol Rev 2018; 70: 39-67.

166. Uchiyama Y, Nakashima M, Watanabe S, et al. Ultra-sensitive droplet digital PCR for detecting a low-prevalence somatic GNAQ mutation in Sturge-Weber syndrome. Sci Rep 2016; 6: 22985.

167. Couto JA, Ayturk UM, Konczyk DJ, et al. A somatic GNA11 mutation is associated with extremity capillary malformation and overgrowth. Angiogenesis 2017; 20: 303-6.

168. Mohammadipanah F, Salimi F. Potential biological targets for bioassay development in drug discovery of Sturge-Weber syndrome. Chem Biol Drug Des 2018; 91: 359-69.

169. Sundaram SK, Michelhaugh SK, Klinger NV, et al. GNAQ Mutation in the venous vascular malformation and underlying brain tissue in Sturge-Weber syndrome. Neuropediatrics 2017; 48: 385-9.

170. Couto JA, Huang L, Vivero MP, et al. Endothelial cells from capillary malformations are enriched for somatic GNAQ mutations. Plast Reconstr Surg 2016; 137: $77 \mathrm{e}-82 \mathrm{e}$.

171. Scholz SL, Moller I, Reis $H$, et al. Frequent GNAQ, GNA11, and EIF1AX mutations in iris melanoma. Invest Ophthalmol Vis Sci 2017; 58: 3464-70.

172. Vader MJ, Madigan MC, Versluis M, et al. GNAQ and GNA11 mutations and downstream YAP activation in choroidal nevi. Br J Cancer 2017; 117: 884-7.

173. Psinakis F, Katseli A, Koutsandrea C, et al. Uveal melanoma: GNAQ and GNA11 mutations in a Greek population. Anticancer Res 2017; 37: 5719-26.

174. Ayturk UM, Couto JA, Hann S, et al. Somatic activating mutations in GNAQ and GNA11 are associated with congenital hemangioma. Am J Hum Genet 2016; 98: 789-95.

175. Higueros E, Roe E, Granell E, Baselga E. Sturge-Weber syndrome: a review. Actas Dermosifiliogr 2017; 108: 407-17.

176. Huang Z, Li Y, Zhao Z, et al. GNAQ mutation R183Q as a potential cause of familial Sturge-Weber syndrome: A case report. Oncol Lett 2017; 13: 2665-9.

177. Hildebrand MS, Harvey AS, Malone S, et al. Somatic GNAQ mutation in the forme fruste of Sturge-Weber syndrome. Neurol Genet 2018; 4: e236.

178. Sapp JC, Turner JT, van de Kamp JM, van Dijk FS, Lowry RB, Biesecker LG. Newly delineated syndrome of congenital lipomatous overgrowth, vascular malformations, and epidermal nevi (CLOVE syndrome) in seven patients. Am J Med Genet A 2007; 143A: 2944-58.

179. Martinez-Lopez A, Blasco-Morente G, Perez-Lopez I, et al. CLOVES syndrome: review of a PIK3CA-related overgrowth spectrum (PROS). Clin Genet 2017; 91: 14-21.

180. Kurek KC, Luks VL, Ayturk UM, et al. Somatic mosaic activating mutations in PIK3CA cause CLOVES syndrome. Am J Hum Genet 2012; 90: 1108-15.

181. Keppler-Noreuil KM, Rios JJ, Parker VE, et al. PIK3CA-related overgrowth spectrum (PROS): diagnostic and testing eligibility criteria, differential diagnosis, and evaluation. Am J Med Genet A 2015; 167A: 287-95.

182. Loconte DC, Grossi V, Bozzao C, et al. Molecular and functional characterization of three different postzygotic mutations in PIK3CA-related overgrowth spec- 
trum (PROS) patients: Effects on PI3K/AKT/mTOR signaling and sensitivity to PIK3 inhibitors. PLoS One 2015; 10: e0123092.

183. Lindhurst MJ, Parker VE, Payne F, et al. Mosaic overgrowth with fibroadipose hyperplasia is caused by somatic activating mutations in PIK3CA. Nat Genet 2012; 44: 928-33.

184. Biesecker LG, Peters KF, Darling TN, et al. Clinical differentiation between Proteus syndrome and hemihyperplasia: description of a distinct form of hemihyperplasia. Am J Med Genet 1998; 79: 311-8.

185. Alomari Al. Characterization of a distinct syndrome that associates complex truncal overgrowth, vascular, and acral anomalies: a descriptive study of 18 cases of CLOVES syndrome. Clin Dysmorphol 2009; 18: 1-7.

186. Riviere JB, Mirzaa GM, O’Roak BJ, et al. De novo germline and postzygotic mutations in AKT3, PIK3R2 and PIK3CA cause a spectrum of related megalencephaly syndromes. Nat Genet 2012; 44: 934-40.

187. Lee JH, Huynh M, Silhavy JL, et al. De novo somatic mutations in components of the PI3K-AKT3-mTOR pathway cause hemimegalencephaly. Nat Genet 2012; 44: 941-5.

188. Mirzaa G, Conway R, Graham JM, Jr., Dobyns WB. PIK3CA-related segmental overgrowth. In: Adam MP, Ardinger HH, Pagon RA, et al. (eds.) Source GeneReviews ${ }^{\circledR}$ [Internet]. University of Washington, Seattle 1993-2019.

189. Janku F, Lee JJ, Tsimberidou AM, et al. PIK3CA mutations frequently coexist with RAS and BRAF mutations in patients with advanced cancers. PLoS One 2011; 6: e22769.

190. Janku F, Wheler JJ, Naing A, et al. PIK3CA mutations in advanced cancers: characteristics and outcomes. Oncotarget 2012; 3: 1566-75.

191. Hawkins PT, Anderson KE, Davidson K, Stephens LR. Signalling through Class I PI3Ks in mammalian cells. Biochem Soc Trans 2006; 34: 647-62.

192. Katso R, Okkenhaug K, Ahmadi K, White S, Timms J, Waterfield MD. Cellular function of phosphoinositide 3-kinases: implications for development, homeostasis, and cancer. Annu Rev Cell Dev Biol 2001; 17: 615-75.

193. Fang X, Zhou X, Wang X. Clinical development of phosphatidylinositol 3-kinase inhibitors for non-Hodgkin lymphoma. Biomark Res 2013; 1: 30.

194. Le LQ, Parada LF. Tumor microenvironment and neurofibromatosis type I: connecting the GAPs. Oncogene 2007; 26: 4609-16.

195. Michel ME, Konczyk DJ, Yeung KS, et al. Causal somatic mutations in urine DNA from persons with the CLOVES subgroup of the PIK3CA-related overgrowth spectrum. Clin Genet 2018; 93: 1075-80.

196. Luks VL, Kamitaki N, Vivero MP, et al. Lymphatic and other vascular malformative/overgrowth disorders are caused by somatic mutations in PIK3CA. J Pediatr 2015; 166: 1048-54.e1-5.

197. Peterman CM, Fevurly RD, Alomari Al, et al. Sonographic screening for Wilms tumor in children with CLOVES syndrome. Pediatr Blood Cancer 2017; 64; doi: 10.1002/pbc.26684.

198. Brouillard P, Vikkula M. Genetic causes of vascular malformations. Hum Mol Genet 2007; 16 Spec No. 2: R140-9.

199. Cox JA, Bartlett E, Lee El. Vascular malformations: a review. Semin Plast Surg 2014; 28: 58-63.

200. Dompmartin A, Vikkula M, Boon LM. Venous malformation: update on aetiopathogenesis, diagnosis and management. Phlebology 2010; 25: 224-35.
201. Kumar S, Kumar V, Kumar S, Kumar S. Management strategy for facial venous malformations. Natl J Maxillofac Surg 2014; 5: 93-6.

202. Killion E, Mohan K, Lee El. A review of vascular anomalies: genetics and common syndromes. Semin Plast Surg 2014; 28: 64-8.

203. Castillo SD, Tzouanacou E, Zaw-Thin M, et al. Somatic activating mutations in Pik3ca cause sporadic venous malformations in mice and humans. Sci Transl Med 2016; 8: 332ra43.

204. Eklund L, Kangas J, Saharinen P. Angiopoietin-Tie signalling in the cardiovascular and lymphatic systems. Clin Sci (Lond) 2017; 131: 87-103.

205. Castel P, Carmona FJ, Grego-Bessa J, et al. Somatic PIK3CA mutations as a driver of sporadic venous malformations. Sci Transl Med 2016; 8: 332ra42.

206. Ruggieri M, Pavone V, Polizzi A, Falsaperla R, Fichera M, Pavone P. Klippel-Trenaunay syndrome in a boy with concomitant ipsilateral overgrowth and undergrowth. Am J Med Genet A 2014; 164A: 1262-7.

207. Karuppal R, Raman RV, Valsalan BP, Gopakumar T, Kumaran CM, Vasu CK. Servelle-Martorell syndrome with extensive upper limb involvement: a case report. J Med Case Rep 2008; 2: 142.

208. Revencu N, Boon LM, Dompmartin A, et al. Germline mutations in RASA1 are not found in patients with Klippel-Trenaunay syndrome or capillary malformation with limb overgrowth. Mol Syndromol 2013; 4: 173-8.

209. Sgubin D, Kanai R, Di Paola F, Perin A, Longatti P. Conus medullaris-cauda arteriovenous malformation and Klippel-Trenaunay syndrome: what is the treatment goal? Neurol Med Chir (Tokyo) 2013; 53: 110-4.

210. Atis A, Ozdemir G, Tuncer G, Cetincelik U, Goker N, Ozsoy S. Management of a Klippel-Trenaunay syndrome in pregnant women with mega-cisterna magna and splenic and vulvar varices at birth: a case report. J Obstet Gynaecol Res 2012; 38: 1331-4.

211. Hu P, Zhang GY, Wang Y, Cheng Y, Wang LL. KlippelTrenaunay syndrome in combination with congenital dislocation of the hip. J Chin Med Assoc 2013; 76: 229-31.

212. Dimopoulos A, Sicko RJ, Kay DM, et al. Copy number variants in a population-based investigation of Klippel-Trenaunay syndrome. Am J Med Genet A 2017; 173: 352-359.

213. Ceballos-Quintal JM, Pinto-Escalante D, Castillo-Zapata I. A new case of Klippel-Trenaunay-Weber (KTW) syndrome: evidence of autosomal dominant inheritance. Am J Med Genet 1996; 63: 426-7.

214. Pereira de Godoy JM, Fett-Conte AC. Dominant inheritance and intra-familial variations in the association of Sturge-Weber and Klippel-Trenaunay-Weber syndromes. Indian J Hum Genet 2010; 16: 26-7.

215. Chen D, Li L, Tu X, Yin Z, Wang Q. Functional characterization of Klippel-Trenaunay syndrome gene AGGF1 identifies a novel angiogenic signaling pathway for specification of vein differentiation and angiogenesis during embryogenesis. Hum Mol Genet 2013; 22 963-76.

216. Tian XL, Kadaba R, You SA, et al. Identification of an angiogenic factor that when mutated causes susceptibility to Klippel-Trenaunay syndrome. Nature 2004; 427: 640-5.

217. Zhan M, Hori Y, Wada N, et al. Angiogenic factor with G-patch and FHA domain 1 (AGGF1) expression in human vascular lesions. Acta Histochem Cytochem 2016; 49: 75-81. 
218. Hu FY, Wu C, Li Y, et al. AGGF1 is a novel anti-inflammatory factor associated with TNF-alpha-induced endothelial activation. Cell Signal 2013; 25: 1645-53.

219. Uhlén M, Fagerberg L, Hallström BM, et al. Proteomics. Tissue-based map of the human proteome. Science 2015; 347: 1260419.

220. Zhang T, Yao Y, Wang J, et al. Haploinsufficiency of Klippel-Trenaunay syndrome gene Aggf1 inhibits developmental and pathological angiogenesis by inactivating PI3K and AKT and disrupts vascular integrity by activating VE-cadherin. Hum Mol Genet 2016; 25: 5094-110.

221. Barker KT, Foulkes WD, Schwartz CE, et al. Is the E133K allele of VG5Q associated with Klippel-Trenaunay and other overgrowth syndromes? J Med Genet 2006; 43: 613-4.

222. Gutierrez S, Magano L, Delicado A, et al. The G397A (E133K) change in the AGGF1 (VG5Q) gene is a single nucleotide polymorphism in the Spanish population. Am J Med Genet A 2006; 140: 2832-3.

223. Vahidnezhad H, Youssefian L, Uitto J. Klippel-Trenaunay syndrome belongs to the PIK3CA-related overgrowth spectrum (PROS). Exp Dermatol 2016; 25: 17-9.

224. Whelan AJ, Watson MS, Porter FD, Steiner RD. Klippel-Trenaunay-Weber syndrome associated with a 5:11 balanced translocation. Am J Med Genet 1995; 59: 492-4.

225. Wang Q, Timur AA, Szafranski P, et al. Identification and molecular characterization of de novo translocation $\mathrm{t}(8 ; 14)(\mathrm{q} 22.3 ; \mathrm{q} 13)$ associated with a vascular and tissue overgrowth syndrome. Cytogenet Cell Genet 2001; 95: 183-8.

226. Puiu I, Stoica A, Sosoi S, Puiu A, loana M, Burada F. Terminal deletion $2 q 37.3$ in a patient with KlippelTrenaunay-Weber syndrome. Fetal Pediatr Pathol 2013; 32: 351-6. 